\title{
Molecular Genetics and Breeding for Nutrient Use Efficiency in Rice
}

\author{
Jauhar Ali ${ }^{1, *,+(\mathbb{D})}$, Zilhas Ahmed Jewel ${ }^{1,+}+\mathbb{C}$, Anumalla Mahender ${ }^{1,+} \mathbb{C}$, Annamalai Anandan ${ }^{2}$, \\ Jose Hernandez ${ }^{3}$ and Zhikang $\mathrm{Li}^{4}$ \\ 1 Rice Breeding Platform, International Rice Research Institute (IRRI), Los Baños, Laguna 4031, Philippines; \\ jeweluplb@gmail.com (Z.A.J.); m.anumalla@irri.org (A.M.) \\ 2 ICAR-National Rice Research Institute, Cuttack, Odisha 753006, India; anandanau@yahoo.com \\ 3 Institute of Crop Science, College of Agriculture and Food Science, University of the Philippines Los Baños, \\ Laguna 4031, Philippines; joehernandez56@gmail.com \\ 4 Institute of Crop Sciences, Chinese Academy of Agricultural Science, Beijing 100081, China; \\ zhkli1953@126.com \\ * Correspondence: J.Ali@irri.org; Tel.: +63-2580-5600 (ext. 2541) \\ + These authors contributed equally to this work.
}

Received: 25 April 2018; Accepted: 1 June 2018; Published: 14 June 2018

\begin{abstract}
In the coming decades, rice production needs to be carried out sustainably to keep the balance between profitability margins and essential resource input costs. Many fertilizers, such as N, depend primarily on fossil fuels, whereas $\mathrm{P}$ comes from rock phosphates. How long these reserves will last and sustain agriculture remains to be seen. Therefore, current agricultural food production under such conditions remains an enormous and colossal challenge. Researchers have been trying to identify nutrient use-efficient varieties over the past few decades with limited success. The concept of nutrient use efficiency is being revisited to understand the molecular genetic basis, while much of it is not entirely understood yet. However, significant achievements have recently been observed at the molecular level in nitrogen and phosphorus use efficiency. Breeding teams are trying to incorporate these valuable QTLs and genes into their rice breeding programs. In this review, we seek to identify the achievements and the progress made so far in the fields of genetics, molecular breeding and biotechnology, especially for nutrient use efficiency in rice.
\end{abstract}

Keywords: NPK fertilizers; agronomic traits; molecular markers; quantitative trait loci

\section{Introduction}

Global rice production increased by three-fold over the past three decades despite rice production constraints and rising input costs. Rice is a nutritionally important cereal crop and staple food of Asia. There is an urgent need for developing high-yielding, nutritious, resource use-efficient and multi-stress-tolerant rice varieties to keep up with the tremendous human population growth, especially in Asia, where rice remains the primary source of caloric intake. The yields of rice grain had seen remarkable improvement during the green revolution and post-green revolution. This increase in yield was primarily achieved through high-input-responsive varieties requiring more chemical fertilizers and pesticides and under an ample supply of irrigation water. This kind of approach that predominated over the past three to four decades now stands exhausted amidst our hope to raise productivity per se sustainably. We are now finding that yields are fast approaching a theoretical limit set by the crop's efficiency in harnessing applied inputs. In exploratory managed experimental plots, $\mathrm{N}$ fertilizer retrieval in a single year averaged $65 \%$ for maize, $57 \%$ for wheat and $46 \%$ for rice $[1,2]$. Alterations in the scale of farming operations and management practices such as tillage, 
seeding, weed and pest control, irrigation and harvesting usually resulted in on-farm variation (lower nutrient use efficiency) and did not accurately reflect the efficiencies obtained in the experimental plot. N recovery efficiency on average ranges from $20-30 \%$ for farmer-managed fields under rainfed conditions, from $30-55 \%$ under irrigated conditions [3,4] and rarely exceeds $50 \%$.

Over the years, the rice varieties bred did not improve in nutrient absorption and were not developed to maximize nutrient absorption, but they have the capacity to use less than $50 \%$ of the applied nutrients. Breeding rice cultivars with improved nutrient use efficiency (NuUE) is becoming a prerequisite for lowering production costs. Such cultivars with NuUE protects the environment by reducing fertilizer application, decreasing the rate of nutrient application losses to ecosystems, decreasing input costs and improving rice yield with a guarantee for sustainability in agriculture while maintaining soil and ground water quality. On the other hand, improvement of NuUE is an essential prerequisite for expanding crop production into marginal lands with low nutrient availability. In light of high energy costs and progressively unpredictable resources, future agricultural systems with concern for improving yield productivity need to be more fruitful and efficient, especially considering fertilizer and irrigation water. In this context, the identification and development of rice varieties with superior grain yield under low input conditions have therefore become a high breeding priority [5]. Even though significant genotypic differences in nitrogen use efficiency exist in rice, genetic selection for this trait has not been carried out systematically [6-8]. This may be primarily because of the complexity involved in the overall phenotype and its evaluation and the non-availability of genetic tools to use. However, with the recent use of high-throughput single nucleotide polymorphism (SNP) markers with ease and high precision, this area of research needs improvement for better understanding [9-11].

Genetic and physiological traits often change with the interaction with environmental variables. Plants are efficient in the absorption and use of nutrients in controlled environments. Therefore, there is a need for a systematic breeding program to develop cultivars with high NuUE and water use efficiency (WUE) [12,13]. The traits involved, particularly nutrient absorption, transport, use and mobilization, should be identified to enhance NuUE and coupled with best management practices for sustainable agriculture.

Use of the wild species of Oryza and native landraces becomes imperative for exploiting the untapped reservoir of useful QTLs and genes, especially to broaden the genetic basis of rice and to enrich existing varieties [14,15]. Genetic selection and plant breeding techniques helped to develop rice varieties that are resistant to pests, diseases and adverse environmental conditions such as drought, submergence and salinity. However, for improving NuUE in rice crop, a proper genetic selection approach is necessary. Superior N-efficient genotypes are required as evidenced from the low recovery of $\mathrm{N}$ fertilizer, associated economic and environmental concerns and the lack of adoption of more efficient $\mathrm{N}$ management strategies $[16,17]$. Nitrogen use efficiency (NUE) mostly depends on interactions and the use of the nutrient in a proper way, water availability, light intensity, disease pressure and genotype, which could also be improved through appropriate genetic manipulation [6]. Plant ability to absorb and use nutrients under various environmental and ecological conditions is largely influenced by the genetic makeup and physiological components [12]. There are two major approaches to understand NuUE. First, the nutrient deficiency stress triggers a response of plants to it, which may lead to the identification of the processes affecting it. It would help us to understand how to sustain plants under low nutrient inputs. The second approach would be to exploit genetic variability (both natural and induced) through innovative molecular breeding schemes.

Molecular linkage genetic maps and quantitative trait locus (QTL) mapping technologies are helpful for estimating the number and position of the loci governing genetic variation using different types of segregating and fixed populations. Characterizing these loci to their map positions in the genome, as well as their phenotypic effects and epistatic interactions with other QTLs and loci [18-21] has enabled us to explore the genetic loci associated with complex traits such as drought, salinity, disease, NuUE and insect resistance in crop plants [18,22-29]. The rapid advancement in genome 
sequencing technologies and marker-aided breeding approaches has resulted in a change in breeding methods, providing new opportunities [5]. Association mapping is a method used to identify genes and QTLs underlying quantitatively inherited variation based on a diverse set of fixed lines. It allows the discovery of QTLs/genes using historical phenotypic data and eventually leads to identifying gene functions, under used alleles and allele combinations that can be useful for crop improvement [30,31]. Genome-wide association mapping depends on the strength of linkage disequilibrium (LD) across a diverse population besides identifying the relationships between markers and traits of agronomic and evolutionary interest [32,33].

Understanding the genetic basis of agronomic, physiological and morphological traits in rice is critical for developing new and improved rice varieties. Rice breeders can use this information to select parental lines for hybridization and screen segregating populations (Figure 1). Recently, researchers have been gaining access to the enormous online wealth of genomic and plant breeding resources, including high-quality genome sequences [34-36], dense SNP maps [37-39], extensive germplasm collections and public databases of genomic information [35,36,39-41]. In this review, we have attempted to gather all the necessary information on QTLs related to N,P and K for the benefit of breeders involved in developing rice varieties with NuUE for sustainable agriculture.

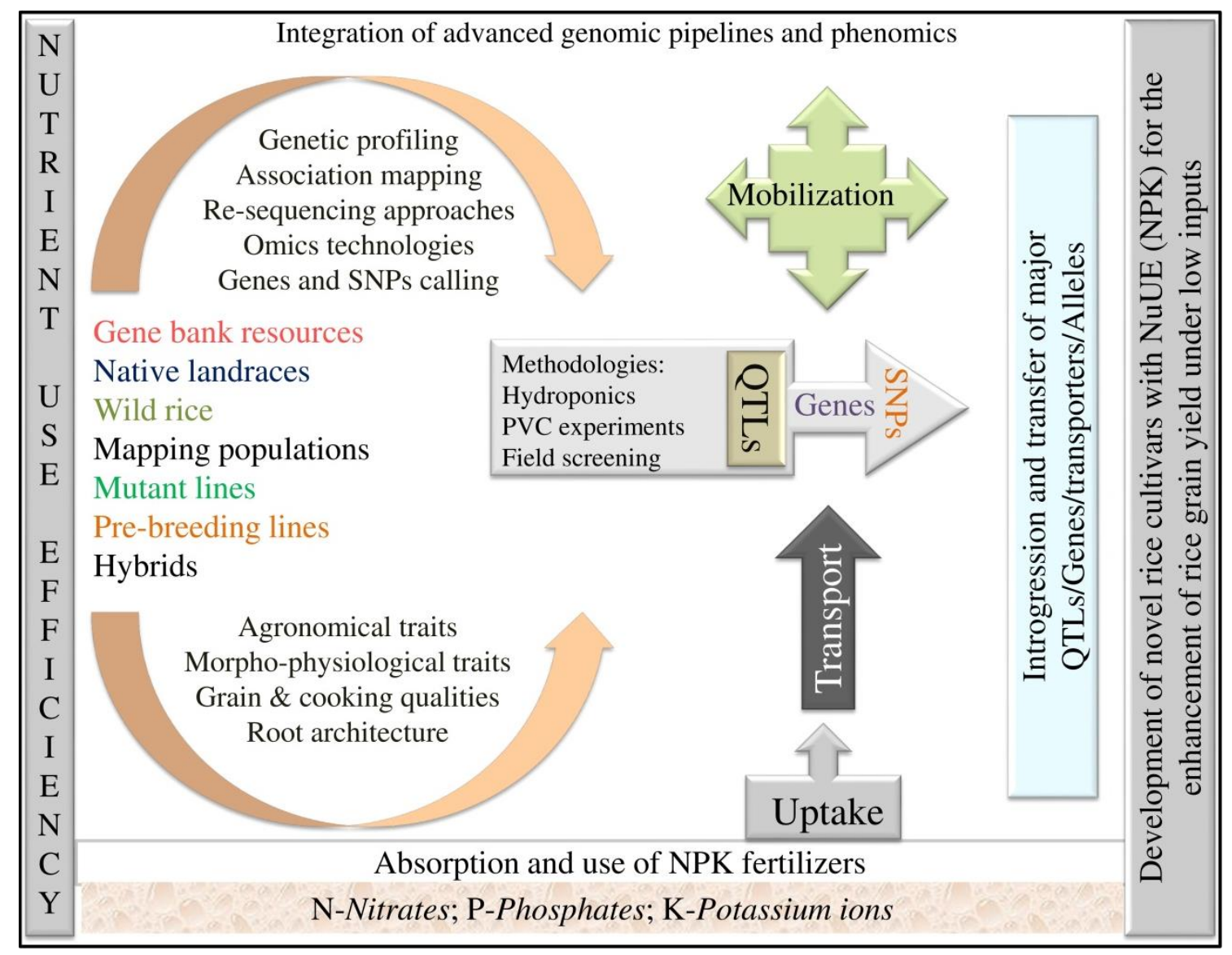

Figure 1. Integrated breeding and genomic approaches for improvement of rice cultivars superior in nutrient use efficiency (NuUE).

\section{Screening Protocols and Breeding Efforts for Traits Related to Nutrient Use Efficiency}

The literature is replete with NuUE screening protocols, especially for varieties, and very few are available for the systematic breeding of varieties with NuUE. Most of these NuUE studies use minus plots for different nutrients under study [42]. Research plots in institutions practice using omission or minus plots for any given target nutrient under study. Furthermore, researchers have always used 
natural sites with nutrient deficiencies for screening for any given nutrient such as the Pangil and Tiaong locations in the Philippines for $\mathrm{P}$ and $\mathrm{Zn}$ _ deficiency conditions, respectively.

\subsection{Phosphorus}

Deficiency of phosphorus is widespread in tropical and temperate acid soils. Screening and breeding for low phosphorus-tolerant (LPT) genotypes are some of the primary criteria for improving the use efficiency of P fertilizers. Worldwide, one-third of cultivable lands lack $\mathrm{P}$ in the soil to meet the requirement for ideal plant growth and development [43]. To avoid these stressful conditions, $\mathrm{P}$ is applied widely as an artificial fertilizer for improving grain yield for the burgeoning global population. The inconsistent use of fertilizers severely reduces income, and extreme conditions may cause environmental pollution [44]. Therefore, to overcome this crisis, the identification and improvement of P-efficient rice genotypes adapted to low-P soils would be a favorable solution for the enhancement of grain yield [45]. Developing P-efficient genotypes started with breeders involved in developing upland rice genotypes in an inadvertent manner. On the other hand, the mega-variety of India Swarna is a widely adaptable and popular variety among farmers perhaps because among its necessary traits is P responsiveness, as it possesses the Pup1 QTL. Therefore, breeders should give more emphasis to developing lines tolerant of $P_{-}$deficiency with high grain yield. Krishnamurthy et al. [46] identified six LPT genotypes as Rasi, IET5854, IET14554, PRH122, IET15328 and IET17467, based on grain yield in field experiments at the Directorate of Rice Research in Hyderabad, India. Fageria et al. [47] reported seven lines (CAN 5164, CAN 4097, CAN 5170, IR3646-8-1-2, CAN 4137, A8-391 and IAC-47) at the National Rice and Bean Research Center of Embrapa in Brazil. In 2015, Saito et al. [48] found two varieties (Mudgo and DJ123) based on aboveground biomass at two locations. The development of such genotypes from diverse rice collections and mapping populations, along with cautious screening methodologies, is essential at the laboratory level to reduce the necessity for large-scale field evaluations. Several researchers used hydroponic nutrient solution and field experiments with different doses of $P$ fertilizer to characterize rice varieties. This identified promising traits involved in tolerance of low P [48-58].

For grain yield and response to a graded level of applied phosphorus in low soil fertility conditions, Krishnamurthy et al. [50]) evaluated 28 pre-release promising rice varieties and hybrids at the Directorate of Rice Research farm in Hyderabad. They followed the protocol of 0-60 $\mathrm{kg} \mathrm{P}_{2} \mathrm{O}_{5} \mathrm{ha}^{-1}$ (i.e., 0, 10, 20, 3040,50 and $60 \mathrm{~kg} \mathrm{P}_{2} \mathrm{O}_{5}$ ha $^{-1}$ ) for the $\mathrm{P}$ application rate. Among the 28 rice varieties, four distinct patterns were identified in response to grain yield. Eight rice varieties at $0-10 \mathrm{~kg} \mathrm{P}_{2} \mathrm{O}_{5} \mathrm{ha}^{-1}$ and six varieties at 20-30 $\mathrm{kg} \mathrm{P}_{2} \mathrm{O}_{5} \mathrm{ha}^{-1}$ exhibited higher grain yield, while five varieties recorded higher grain yield in responses at higher $\mathrm{P}$ rates of $50-60 \mathrm{~kg} \mathrm{P}_{2} \mathrm{O}_{5} \mathrm{ha}^{-1}$. Out of the 28 varieties, three lines (IET 17190, Sumati and Rajavadlu) did not show any significant change in grain yield at 0-10 or 50-60 kg $\mathrm{P}_{2} \mathrm{O}_{5} \mathrm{ha}^{-1}$, indicating the existence of genetic variability for P-use efficiency. Chin et al. [58] suggested a soil-based screening method as the most favorable approach for identifying genotypes with tolerance of $P_{-}$deficiency. Aluwihare et al. [53] experimented with Ultisol soils, without any application of fertilizer for four decades at Rice Research and Development Institute (RRDI), Sri Lanka, and this also confirmed the absence of P [58]. At P0 and $\mathrm{P} 30\left(30 \mathrm{mg} / \mathrm{kg} \mathrm{P}_{2} \mathrm{O}_{5}\right)$ conditions, during early vegetative, late vegetative and flowering stages, plant height $(\mathrm{PH})$, number of tillers (NT), SDW (shoot dry weight), SPC (shoot P concentration), SPU (shoot P uptake) and PUE (P use efficiency) were found to be the major indicators for $\mathrm{P}_{-}$deficiency tolerance (PDT). Among the total genotypes, 13 were considered as highly tolerant, 13 as moderate and 4 as sensitive to $\mathrm{P}_{-}$deficiency based on SDW and $\mathrm{P}$ use efficiency under P0 conditions. Cancellier et al. [59] and Fageria et al. [60] elucidated that plant height is a vital morphological trait for PDT screening as it significantly correlates with dry weight and yield. Panigrahy et al. [61] identified four low P-tolerant and four susceptible mutants by screening 300-ethane methane sulfonate (EMS)-induced (Nagina 22 [N22]) mutants under low-P field conditions.

However, experimentations at the gene expression level were carried out in controlled test tube, Petri plate or potted conditions with different rates of nutrients, which often included the zero 
condition (control) for less than a month's duration [13,62,63]. Li et al. [64] carried out expression profile studies using a DNA chip by subjecting rice at 6,24 and $72 \mathrm{~h}$ under low-P stress and compared to a control treatment under normal $\mathrm{P}$ conditions. The study showed that genes directly involved in phosphorus absorption and use did not change significantly in transcription in rice shoots, relating to the inadequate low-P treatment. At $72 \mathrm{~h}$ under low phosphorus limitation, rice shoots did not develop severe phosphorus stress [65].

Specific genotypes known for their susceptibility to nutrient deficiency stress are useful for selection purposes, especially for different target nutrients. $\mathrm{P}_{-}$deficiency tolerance was identified in a rice population derived from a cross between P-inefficient japonica cultivar "Nipponbare" and P-efficient indica landrace "Kasalath" [65].

On the other hand, several traits were studied to understand the phenotyping behavior of plants for precision screening and to progress in breeding activities. Root dry weight (RDW) is an important feature for evaluating the selection index for low-P tolerance in rice. Li et al. [49] reported that, at the seedling stage, dry weight had a significant genotypic variation (19.60\%) in both standard and low-P conditions. TDW correlated with RRDW (relative root dry weight), RPH (relative plant height), RPUP (relative total P uptake), RSPA (relative shoot P accumulation), RPUE (relative P use efficiency) and RPC (relative P concentration) at $p<0.01$. Several key morphological and physiological traits such as plant height, number of tillers, shoot root length, relative shoot and root dry weight and leaf age and root-attributed traits such as root diameter, root hair number and number of roots were used for screening and identifying tolerant genotypes under $P_{-}$deficiency conditions $[61,66-70]$. Increasing the productivity of grain yield under $\mathrm{P}_{-}$deficiency conditions, increasing $\mathrm{P}$ taken up from the soil and improving the dry matter of internal use of $P$ help to enhance the number of panicles and grain productivity $[53,71]$. Relative tiller dry weight (RTW), shoot dry weight and plant dry weight used as better screening criteria for identifying genotypes tolerant of low-P stress, especially RTW being sensitive, proved to be a reliable screening test. In recent days, image analysis has been becoming popular in high-throughput screening. Chen et al. [72] established an accurate, fast and operable method for diagnosing the crop nutrition status of NPK deficiencies in the color and shape of leaf parameters using a static scanning technology (SST) and hierarchical method in a pot experiment.

\subsection{Nitrogen}

Nitrogen fertilizer is an essential element for many aspects to improve grain yield, grain quality, flowering time and root development for extracting water and other nutrient elements from the soil $[73,74]$. On the other hand, the application of $\mathrm{N}$ is not uniform in all geographic regions of nations worldwide [75]. Several morphological and agronomic factors were found to influence the deficiency or high rates of $\mathrm{N}$. Higher rates of $\mathrm{N}$ fertilizer consumption repeatedly led to environmental pollution and decreased nitrogen use efficiency (NUE) [76]. Therefore, the immediate focus should be to exploit the available variability in the use efficiency of rice cultivars through classical plant breeding methods and advanced biotechnological approaches to increase NUE in rice. Numerous research efforts have been conducted with different rates of $\mathrm{N}$ fertilizer in field experiments and hydroponic nutrient solution, and this was correlated with $\mathrm{N}$ use-efficient genotypes and higher grain yield (GY) parameters [77-79]. Chaturvedi [80] conducted a field experiment with different treatments of $\mathrm{N}$ fertilizer at the Agricultural Research Station in Chhattisgarh, India. Using an application of sulfur-containing nitrogenous fertilizer (Super Net) has significantly increased the grain yield and grain nitrogen content in hybrid rice variety Proagro 6207. Manzoor et al. [81] directed an experiment with nine different $\mathrm{N}$ rates (i.e., 0, 50, 75, 100, 125, 150, 175, 200 and $225 \mathrm{~kg} \mathrm{ha}^{-1}$ ) at the Rice Research Institute in Lahore, Pakistan, with Super basmati. Interestingly, at $200 \mathrm{~kg} \mathrm{~N} \mathrm{ha}^{-1}$ and above, yield-attributed traits declined, and higher grain yield, number of grains per panicle, 1000-grain weight, number of tillers and panicle length significantly improved at $175 \mathrm{~kg} \mathrm{~N} \mathrm{ha}^{-1}$.

Likewise, Swamy et al. [82] evaluated ten rice genotypes under recommended rates of nitrogen (100 kg N ha ${ }^{-1}$ ) and deficient $\mathrm{N}$ as no external nitrogen (i.e., N0) in a treatment grown in field 
conditions at Indian Institute of Rice Research (IIRR), Hyderabad. They found that $14 \%$ of root length (RL) decreased significantly under $\mathrm{N}_{-}$deficiency. Haque and Haque [83] detected higher grain yield

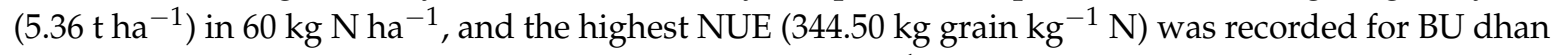
1 at six different $\mathrm{N}$ rates $\left(0,20,40,60,80\right.$ and $\left.100 \mathrm{~kg} \mathrm{~N} \mathrm{ha}^{-1}\right)$; they found an intermediate rate of $\mathrm{N}$ as economical and environment-friendly.

Employing a hydroponic experiment, Nguyen et al. [74] determined the effect of $\mathrm{N}$ supply in low and excess $\mathrm{NH}_{4} \mathrm{NO}_{3}$ concentration in Yoshida nutrient solution using three rice cultivars: IR64 (Oryza sativa ssp. indica), Azucena (O. sativa ssp. japonica) and TOG7105 (O. glaberrima). The rate of absorption of NUE (aNUE) and agronomic NUE (agNUE) decreased significantly, although at a gradual pace as the N supply increased, and physiological NUE (pNUE) declined progressively upon lowering the N supply.

To minimize $\mathrm{N}$ application and to use available $\mathrm{N}$ more efficiently, agronomic practices still need to be standardized. Nitrogen use efficiency is a complex trait and is associated with different components such as pNUE, aNUE, agNUE $[77,78,84]$ and alteration in morpho-agronomic and physiological traits such as plant height, tiller number, grain yield, dry weight of shoots and roots, spikelet number, number of filled grains per panicle, 1000-grain weight, the leaf color chart (LCC) and chloroplasts $[25,26,74,81,83,85-91]$ in rice. Alteration of the main traits was influenced by the response of $\mathrm{N}$ fertilizers, which may enhance the availability of $\mathrm{N}$, which can lead to higher photo-assimilates and dry matter accumulation [80,92]. Therefore, considering the absorption, physiological and agronomic NUEs associated with morpho-agronomic traits will help to attain the balance between high grain yield and the eco-friendly nature of farm systems, which would be useful in developing crops with superior NUE.

\subsection{Potassium}

The availability of $\mathrm{K}$ in the soil is insufficient in developing countries, and it plays a significant role in crop grain yield and quality [93]. From 2012-2016, K fertilizer consumption globally increased from 28.6 Mt $\left(\mathrm{K}_{2} \mathrm{O}\right)$ to $33.2 \mathrm{Mt}\left(\mathrm{K}_{2} \mathrm{O}\right)$ [94]. Notably, East and South Asia are promising agricultural areas consuming $44.9 \%$ of the world $\mathrm{K}$ fertilizer, which is not adequate for improving grain yield under deficiency of K. The price of K fertilizers increased rapidly from 2003 (USD 165 per ton) to 2013 (USD 595 per ton) [94]. Therefore, the identification of K use efficiency (KUE) in rice is essential and needs to be used in developing genotypes with higher grain yield for K-deficient conditions. Dobermann et al. [95] mentioned that, as compared with other cereal crops, rice acquires $56-112 \mathrm{~kg}$ of $\mathrm{K}$ from soils in each harvest of yield of $4-8 \mathrm{tha}^{-1}$, and yearly $\mathrm{K}$ demand for irrigated rice would be $9-15 \times 106$ tons by 2025 . In physiological aspects, $\mathrm{K}$ is involved in many functions related to regulating osmotic potential, transporting assimilates, root development for uptaking water and nutrients, reducing the frequency of diseases, drought tolerance and photosynthetic activity [96-99]. Under different rates of $\mathrm{K}$ fertilizer $\left(0,25,50,75\right.$ and $\left.100 \mathrm{~kg} \mathrm{ha}^{-1}\right)$, Mehdi et al. [100] evaluated the response of rice cultivars in saline-sodic soil during 2005 and achieved the highest paddy yield (3.24 $\left.\mathrm{t} \mathrm{ha}^{-1}\right)$ and straw yield $\left(3.92 \mathrm{t} \mathrm{ha}^{-1}\right)$ at $100 \mathrm{~kg} \mathrm{~K}_{2} \mathrm{O} \mathrm{ha}^{-1}$. Similarly, Fageria et al. [101] elucidated lowland rice grain yield varying from 5.88-6.24 $\mathrm{tha}^{-1}$ with an application of $125 \mathrm{~kg} \mathrm{ha}^{-1}$ in different years. Analysis of six upland rice genotypes evaluated in a greenhouse under natural soil of $200 \mathrm{mg} \mathrm{K} \mathrm{kg}^{-1}$ revealed that $\mathrm{K}$ uptake in shoot and grain and the $\mathrm{K}$ use efficiency ratio (KUER) were significantly and positively associated with grain yield [101], whereas, compared with grain, K concentration and uptake were higher in shoots. Arif et al. [102] conducted a pot experiment with three genotypes in a rain-protected wire house at the University of Agriculture in Faisalabad using hydroponic nutrient solution with different $\mathrm{K}$ rates of $0,30,60,90$ and $120 \mathrm{~kg} \mathrm{ha}^{-1}$, respectively. Among the three genotypes, IR6 (low KUE), Super basmati (medium KUE), genotype 99509 (high KUE), the highest thousand grain weight (TGW) (IR6), grain yield $\left(\mathrm{g} \mathrm{pot}^{-1}\right.$ ) (Super basmati, 99509), number of panicles and tillers per pot (Super basmati) were recorded at optimum rates of $60 \mathrm{~kg} \mathrm{ha}^{-1}$. Earlier reports revealed that a higher rate of $\mathrm{K}$ influences increases in yield-attributed 
traits [103-106]. The increase in yield with an optimum rate of K plays a crucial role in increased $\mathrm{N}$ use and increasing chlorophyll synthesis and translocation of assimilates to reproductive parts [107]. Recently, Islam et al. [108] compared the application of $K$ fertilizer between 40 and $80 \mathrm{~kg} \mathrm{ha}^{-1}$ in a randomized complete block design. The significant $(p<0.05)$ increases in grain and straw yield in the treatment with $\mathrm{K}$ application rates of 40 and $80 \mathrm{~kg} \mathrm{ha}^{-1}$ were $54 \%$ and $68 \%$ in the dry season and $39 \%$ and $45 \%$ in the wet season from 2003-2010 in field experiments at the Bangladesh Rice Research Institute farm. Hence, improving uptake, transport and translocation of $\mathrm{K}$ efficiency in shoots and rice grain is possible for identifying superior genotypes to further enhance grain yield by proper management practices.

\section{Identification and Use of QTLs Related to Nutrient Use Efficiency}

Developing rice varieties with multiple tolerance is possible provided large-effect QTLs/genes are available and exploited with innovative molecular breeding approaches. The number of reported QTLs is unwaveringly increasing day by day, but still, very few are applied in breeding programs. Obtaining more data that validate QTLs/genes in different genetic backgrounds and environments is a prerequisite for their large-scale application. In rice, there is an attempt to bring a few large-effect QTLs that confer tolerance of submergence, drought, salinity and P deficiency together through molecular marker-assisted breeding. Pup1 is the best model for exploiting the NuUE QTLs currently being used, for which molecular markers are now available and evaluated in different genetic backgrounds under field conditions [5].

\subsection{QTLs Related to Nitrogen Use Efficiency}

Among the essential nutrient elements, nitrogen is the most important one for rice growth in natural ecosystems. The green revolution, which was a breakthrough in agricultural production to secure human nutrition in the past century, depended mainly on fertilizer application and high-yielding modern varieties [109-113]. In this context, nitrogen use-efficient crop varieties are of great concern. Further, genes and QTLs related to agronomy for NUE are presented in Tables 1 and 2. Deeper understanding of the molecular basis of NUE would enable us to provide valuable information for crop improvement through biotechnological approaches. Recent advances in genomics and proteomics approaches such as subtractive hybridization, differential display and microarray techniques are transforming our approach to identify the candidate genes that play a crucial role in the regulation of NUE [4,7,114-118]. In addition, marker-trait association for NUE through quantitative real-time polymerase chain reaction (RT-PCR) technology is being used [119-121]. The identification of potential candidate genes/proteins will serve as biomarkers in the regulation of NUE for screening genotypes for their nitrogen responsiveness. This will help to optimize nitrogen inputs in agriculture.

The modern rice varieties were all selected earlier for higher $\mathrm{N}$ uptake to obtain maximum grain yields. Conversely, the biggest problem with the increased $\mathrm{N}$ supply often leads to a decrease in $\mathrm{N}$ use efficiency. This is mainly due to high $\mathrm{N}$ uptake before flowering, but is also due to low $\mathrm{N}$ uptake during the reproductive growth phase and incomplete $\mathrm{N}$ translocation from vegetative plant parts to the grains $[15,178]$. Sustainable agriculture requires developing crop varieties with high yield potential and less dependency on heavy applications of N and P fertilizer. Similar to P, N has no systematic breeding program and screening protocol. The genotypes were screened either in nutrient minus fields or under solution culture.

In recent years, heavy nitrogen fertilization during panicle development has been popular in China to improve population dynamics and increase grain yield [179]. Panicle fertilization was adopted to increase grain yield and $\mathrm{N}$ recovery efficiency at IRRI [180]. Nitrogen use efficiency positively correlates with photosynthetic characteristics. The measures for promoting photosynthetic function and delaying senescence of leaves may indirectly enhance $\mathrm{N}$ absorption and use of rice and ultimately increase NUE. Some research efforts had been devoted to developing genotypes that use $\mathrm{N}$ more 
efficiently. This highly complicated objective requires an in-depth understanding of the genetic basis of $\mathrm{N}$ assimilation and $\mathrm{N}$ use at different developmental stages. The QTLs underlying related traits toward the late developmental stage in rice at two different nitrogen rates were investigated using a population of chromosome segment substitution lines (CSSLs) derived from a cross between Teqing and Lemont. A total of 31 QTLs referencing five traits, especially plant height, panicle number per plant, chlorophyll content, shoot dry weight and grain yield per plant, were detected. Under the normal nitrogen $\left(150 \mathrm{~kg} / \mathrm{h}^{-1} \mathrm{~N}\right.$ fertilizer) rate, three QTLs were identified for each trait, and the under low nitrogen $(0 \mathrm{~N})$ rate, five, four, five and two QTLs were detected for plant height, panicle number per plant, chlorophyll content and shoot dry weight, respectively. Most of the QTLs were located on chromosomes 2, 3, 7, 11 and 12 [166].

Table 1. Rice genes/QTLs governing key agronomic traits, the protein encoded, level of allele expression and their possible use in breeding programs.

\begin{tabular}{|c|c|c|c|c|c|}
\hline S. No. & Traits & Name of QTL & Encoded Protein & $\begin{array}{c}\text { Nature of Allele Suitable } \\
\text { for Use in Breeding } \\
\text { Programs }\end{array}$ & References \\
\hline 1 & Grain number & Gn1a & Cytokinin oxidase & Low expression & [122] \\
\hline 2 & Grain number and strong culm & dep1 & PEBP-like domain protein & Loss of function & [123] \\
\hline 3 & Grain number & WFP & OsSPL14 & High expression & [124] \\
\hline 4 & $\begin{array}{l}\text { Grain number, low tiller } \\
\text { number, and strong culm }\end{array}$ & Ipa & OsSPL14 & High and ectopic expression & [125] \\
\hline 5 & Grain size & gs3 & Transmembrane protein & Loss of function & [126] \\
\hline 6 & Grain size and filling & gw2 & RING-type ubiquitin E3 ligase & Loss of function & [127] \\
\hline 7 & Grain size & qSW5/GW5 & Unknown & Loss of function & [128] \\
\hline 8 & Grain filling & GIF1 & Cell wall invertase & $\begin{array}{l}\text { Restricted expression in the } \\
\text { ovular vascular trace }\end{array}$ & [129] \\
\hline 9 & Heading date & Hd1 & CONSTANS-like protein & $\begin{array}{l}\text { Loss-of-function allele leads } \\
\text { to late heading }\end{array}$ & [130] \\
\hline 10 & Heading date & Hd6 & Subunit of protein kinase & $\begin{array}{l}\text { Loss-of-function allele leads } \\
\text { to early heading }\end{array}$ & [131] \\
\hline 11 & Heading date & Hd3a & FT-like & $\begin{array}{c}\text { Low expression leads to late } \\
\text { heading }\end{array}$ & [132-134] \\
\hline 12 & Heading date & Ehd1 & B-type response regulator & $\begin{array}{l}\text { Loss-of-function allele leads } \\
\text { to late heading }\end{array}$ & [135] \\
\hline 13 & $\begin{array}{l}\text { Grain number, plant height and } \\
\text { heading date }\end{array}$ & Ghd7 & $\mathrm{CCT}$ domain protein & Functional allele & [136] \\
\hline 14 & Days to heading & DTH8 & CCT domain protein & Functional allele & [137] \\
\hline 15 & Plant height & sd1 & Gibberellin 20 oxidase & Loss of function & [138] \\
\hline 16 & Lodging resistance & SCM2 & F-box protein & High expression & [139] \\
\hline 17 & Disease resistance & pi21 & Proline-rich protein & Loss of function & [140] \\
\hline 18 & Disease resistance & $\mathrm{Pb} 1$ & CC-NBS-LRR protein & Functional allele & [141] \\
\hline 19 & Salt tolerance & SKC1 & HKT-type transporter & Gain of function & [142] \\
\hline 20 & Cold tolerance & qLTG3-1 & GRP and LTP domain & Functional allele & [143] \\
\hline 21 & Submerge tolerance & Sub1A & ERF-related factor & Gain of function & [144] \\
\hline 22 & $\begin{array}{l}\text { Internode elongation under } \\
\text { submergence conditions }\end{array}$ & SK2 & ERF-related factor & Gain of function & [145] \\
\hline 23 & Cadmium accumulation & OsHMA3 & $\begin{array}{l}\text { Putative heavy metal } \\
\text { transporter }\end{array}$ & Functional allele & [146] \\
\hline 24 & Seed shattering & $\operatorname{sh} 4$ & Myb3 transcription factor & Loss of function & [147] \\
\hline 25 & Seed shattering & qSH1 & BEL1-like homeobox protein & $\begin{array}{l}\text { Low expression in } \\
\text { abscission layer between } \\
\text { panicle and spikelet }\end{array}$ & [148] \\
\hline 26 & Prostrate growth & PROG1 & Zinc finger transcription factor & Loss of function & {$[149,150]$} \\
\hline 27 & Disease resistance & RHBV & NS3 protein & $\begin{array}{l}\text { Favorable gene or } \\
\text { QTL alleles }\end{array}$ & [151] \\
\hline 28 & Phosphorus uptake & Pup1 & OsPupK46-2 & High expression & [57] \\
\hline 29 & Deep rooting & DRO1 & Auxin signaling pathway & Functional allele & [152] \\
\hline
\end{tabular}


Table 2. Quantitative trait loci identified for traits related to nitrogen, phosphorus and potassium use efficiency in rice.

\begin{tabular}{|c|c|c|c|c|c|c|}
\hline Entry & & Phosphorus & & & & \multirow{3}{*}{ Reference } \\
\hline \multirow{2}{*}{ S. No. } & \multirow{2}{*}{ Traits } & \multirow{2}{*}{ Population } & \multirow{2}{*}{ Cross } & \multicolumn{2}{|c|}{ No. of QTLs } & \\
\hline & & & & $\mathbf{M}$ & $\mathrm{E}$ & \\
\hline 1 & $\begin{array}{l}\text { Phosphorus uptake, plant dry weight, tiller number; } \\
\text { phosphorus use efficiency }\end{array}$ & NILs & Nipponbare/Kasalath & 8 & - & [65] \\
\hline 2 & $\begin{array}{l}\text { Relative tillering ability, relative shoot dry weight, } \\
\text { relative root dry weight }\end{array}$ & RILs & IR20/IR55178 & 4 & - & [153] \\
\hline 3 & Phosphorus uptake, tiller number & NIL & Nipponbare/Kasalath & 1 (Pup) & - & [154] \\
\hline 4 & $\begin{array}{l}\text { Root elongation, shoot dry weight, relative } \\
\text { phosphorus content, relative Fe content }\end{array}$ & $\mathrm{F}_{8}$ & Gimbozu/Kasalath & 6 & - & [155] \\
\hline 5 & $\begin{array}{l}\text { Relative root length, relative shoot length, relative } \\
\text { shoot dry weight, relative root dry weight }\end{array}$ & BILs & OM2395/AS996 & 1 & - & [156] \\
\hline 6 & Root elongation under phosphorus deficiency & CSSLs & $\begin{array}{l}\text { Nipponbare/Kasalath } \\
\text { CSSL29 }\end{array}$ & 1 & - & [157] \\
\hline 7 & $\begin{array}{l}\text { Plant height, maximum root length, root number, } \\
\text { root volume, root fresh weight, root dry weight, } \\
\text { shoot dry weight, total dry weight, root/shoot dry } \\
\text { weight ratio }\end{array}$ & ILs & Yuefa/IRAT109 & 24 & 29 & [63] \\
\hline 8 & $\begin{array}{l}\text { Relative root length, relative root dry weight, } \\
\text { relative shoot dry weight, relative total dry weight, } \\
\text { relative root-shoot ratio of dry weight }\end{array}$ & $\mathrm{BC}_{2} \mathrm{~F}_{4}$ & Shuhui 527/Minghui 86 & 48 & - & [158] \\
\hline 9 & $\begin{array}{l}\text { Total aboveground biomass, harvest index, } \mathrm{P} \text { use } \\
\text { efficiency for grain yield based on } \mathrm{P} \text { accumulation } \\
\text { in grains, } \mathrm{P} \text { harvest index, } \mathrm{P} \text { translocation, } \mathrm{P} \\
\text { translocation efficiency, } \mathrm{P} \text { total aboveground } \mathrm{P} \\
\text { uptake, } \mathrm{P} \text { use efficiency for biomass accumulation, } \\
\mathrm{P} \text { use efficiency for grain yield, } \mathrm{P} \text { use efficiency for } \\
\text { straw dry weight based on P accumulation in straw }\end{array}$ & RILs & Zhenshan 97/Minghui 63 & 36 & - & [159] \\
\hline 10 & $\begin{array}{l}\text { Root dry weight, relative shoot dry weight, relative } \\
\text { total dry weight }\end{array}$ & DHs & ZYQ8/JX17 & 6 & - & [160] \\
\hline \multicolumn{7}{|c|}{ Nitrogen } \\
\hline 1 & Plant height & DHs & IR64/Azucena & 10 & - & [161] \\
\hline 2 & Rubisco, total leaf nitrogen, soluble protein content & BILs & Nipponbare/Kasalath & 15 & - & [162] \\
\hline 3 & $\begin{array}{l}\text { N uptake (NUP), grain yield, biomass yield, } \mathrm{N} \text { use } \\
\text { efficiency (NUE) }\end{array}$ & CSSLs & 9311/Nipponbare & 13 & & [118] \\
\hline 4 & $\begin{array}{l}\text { Toot system architecture, NDT, and morphological } \\
\text { and physiological traits }\end{array}$ & CSSLs & Curinga/IRGC105491 & 13 & & [163] \\
\hline 5 & Twelve physiological and agronomic traits & RILs & IR64/Azucena & 63 & & [27] \\
\hline 6 & Glutamine synthetase, glutamate synthase & BILs & Nipponbare/Kasalath & 13 & - & [164] \\
\hline 7 & $\begin{array}{l}\text { Glutamine synthetase, panicle number per plant, } \\
\text { panicle weight }\end{array}$ & NILs & Koshihikari/Kasalath & 1 & - & [164] \\
\hline 8 & $\begin{array}{l}\text { Total grain nitrogen, total shoot nitrogen, nitrogen } \\
\text { uptake, nitrogen use efficiency, nitrogen } \\
\text { translocation efficiency }\end{array}$ & $\mathrm{F}_{3}$ & Basmati370/ASD16 & 43 & - & [165] \\
\hline 9 & Root dry weight, shoot dry weight, biomass & RILs & Zhenshan97/Minghui 63 & 52 & 103 & [166] \\
\hline 10 & $\begin{array}{l}\text { Plant height, panicle number per plant, chlorophyll } \\
\text { content, shoot dry weight }\end{array}$ & CSSLs & Teqing/Lemont & 31 & - & [167] \\
\hline 11 & $\begin{array}{l}\text { Total grain number, total leaf nitrogen, total shoot } \\
\text { nitrogen, nitrogen uptake, specific leaf nitrogen }\end{array}$ & RILs & IR69093-4-3-2/IR72 & 32 & - & [168] \\
\hline 12 & $\begin{array}{l}\text { Root length, root thickness, root biomass, } \\
\text { biomass, etc. }\end{array}$ & RILs & Bala/Azucena & 17 & - & [169] \\
\hline 13 & $\begin{array}{l}\text { Relative root dry weight, spikelet number per } \\
\text { panicle, spikelet fertility, 1000-grain weight }\end{array}$ & ILs & $\begin{array}{l}\text { Shuhui } 527 \times \text { Minghui } \\
86\end{array}$ & 48 & & [170] \\
\hline 14 & $\begin{array}{l}\text { Total grain number, total leaf nitrogen, total shoot } \\
\text { nitrogen, physiological nitrogen-use } \\
\text { efficiency, biomass }\end{array}$ & RILs & Dasanbyeo/TR22183 & 20 & 58 & [170] \\
\hline 15 & Total plant nitrogen, nitrogen-use efficiency & DHs & IR64/Azucena & 16 & - & [171] \\
\hline
\end{tabular}


Table 2. Cont.

\begin{tabular}{|c|c|c|c|c|c|c|}
\hline Entry & & Phosphorus & & & & \multirow{3}{*}{ Reference } \\
\hline \multirow{2}{*}{ S. No. } & \multirow{2}{*}{ Traits } & \multirow{2}{*}{ Population } & \multirow{2}{*}{ Cross } & \multicolumn{2}{|c|}{ No. of QTLs } & \\
\hline & & & & $\mathbf{M}$ & $\mathrm{E}$ & \\
\hline 16 & $\begin{array}{l}\text { Total plant nitrogen, nitrogen dry matter } \\
\text { production efficiency, nitrogen grain production } \\
\text { efficiency, total grain number }\end{array}$ & RIL & Dasanbyeo/TR22183 & 28 & 23 & [172] \\
\hline 17 & Grain yield per plant, biomass, harvest index, etc. & RILs & IR64/INRC10192 & 46 & - & [173] \\
\hline 18 & $\begin{array}{l}\text { Plant height, root dry weight, shoot dry weight, } \\
\text { chlorophyll content, root length, biomass }\end{array}$ & RILs & R9308/Xieqingzao B & 7 & - & [161] \\
\hline 19 & Grain yield per plant, grain number per panicle & RILs & Zhenshan 97/HR5 & 19 & 11 & [174] \\
\hline 20 & $\begin{array}{l}\text { Number of panicles per plant, number of spikelets } \\
\text { per panicle, number of filled grains per panicle, } \\
\text { grain density per panicle }\end{array}$ & RILs & $\begin{array}{l}\text { Xieqingzao B/Zhonghui } \\
9308\end{array}$ & 52 & - & [175] \\
\hline 21 & $\begin{array}{l}\text { Nitrogen deficiency tolerance and } \\
\text { nitrogen-use efficiency }\end{array}$ & RILs & $\begin{array}{l}\text { Zhenshan } 97 \text { and } \\
\text { Minghui } 63\end{array}$ & 12 & & [176] \\
\hline \multicolumn{7}{|c|}{ Potassium } \\
\hline 1 & $\begin{array}{l}\text { Plant height, tiller number, shoot and root } \\
\text { oven-dry weight }\end{array}$ & DHs & IR64/Azucena. & 4 & - & [177] \\
\hline
\end{tabular}

Based on the use of two $\mathrm{N}$ supply levels, $5 \mathrm{mg} \mathrm{N} \mathrm{L}^{-1}$ for low $\mathrm{N}$ and $40 \mathrm{mg} \mathrm{N} \mathrm{L}^{-1}$ [167] for high N, QTLs for plant height in rice were mapped onto the Restriction Fragment Length Polymorphism (RFLP) linkage map of a doubled-haploid population derived from a cross between IR64 and Azucena. Two QTLs, one on chromosome 1 and the other on chromosome 8, were detected at high $\mathrm{N}$ levels (40 mg N L ${ }^{-1}$ ) in soil-based nutrient solution culture experiments. Furthermore, a total of eight QTLs were identified at low $\mathrm{N}$ level and located on chromosomes 1, 2, 3, 4, 5 and 6, whereas the QTL flanked by molecular markers RZ730 and RZ801 on chromosome 1 was identified in all experimental conditions. The hypothesis suggests that the genotype showing higher $\mathrm{N}$ efficiency under low $\mathrm{N}$ level may carry the gene(s) for higher $\mathrm{N}$ efficiency. This study demonstrated that the effects of low $\mathrm{N}$ stress on plant height lessened. In the present study, the female parent IR64 was found to have a relatively higher $\mathrm{N}$ efficiency than the male parent Azucena under low $\mathrm{N}$ levels due to its lesser decline in plant height than Azucena. Furthermore, some of the QTLs associated with plant height were detected only at low $\mathrm{N}$ levels and might have some relationship with $\mathrm{N}$ efficiency [162]. QTL analysis was related to $\mathrm{N}$ and $\mathrm{P}$ tolerance traits such as root length at the seedling stage, productive panicles, seed setting ratio and yield. A few QTLs out of these were found to be located on similar chromosomal sections that showed the genes associated with the $\mathrm{N}$ or P metabolism pathway $[181,182]$. QTLs for rice panicle number and grain yield were detected under low nitrogen (N0) and low phosphorus (P0) conditions and helped to analyze the genetic basis of tolerance of soil nutrient deficiency. A total of 125 CSSLs with relatively few introgression segments were derived from japonica cultivar Nipponbare within the genetic background of indica cultivar 93-11. These were screened using an augmented design in field experiments with regular fertilization (NF), low nitrogen (N0) and low phosphorus (P0) treatments. Grain yield and panicle number per plant were measured for each CSSL, and their relative values based on regular fertilization treatment considered as the measurement for tolerance of the nutrient deficiency. Both regular fertilization and low phosphorus treatments showed adverse effects on grain yield and panicle number. The different responses observed among the CSSLs refer to the deficiency of nitrogen or phosphorus. The relative traits had a significantly negative correlation with the traits in the regular fertilizer treatment. Cultivar 93-11 showed higher tolerance of low-nutrient stresses than Nipponbare. The negative allelic effects of 38 QTLs were contributed by Nipponbare under nitrogen and phosphorus deficiency stresses. Out of these, 26 QTLs were responsible for yield and panicle number, and the remaining 12 QTLs specified the relative traits. Five QTLs were identified in common under both stresses. Moreover, $81 \%$ of the QTLs were specifically detected only in low nitrogen (N0) 
or phosphorus (P0) conditions. These different QTLs suggest that the response to limiting nitrogen and phosphorus conditions was regulated by various sets of genes in rice [168].

The application of $\mathrm{N}$ fertilizer is of particular importance for cultivating high-yielding rice. However, heavy nitrogen fertilizer uses with high loss of nitrogen in rice-growing areas have led to low $\mathrm{N}$ recovery rates and environmental pollution. Grain yields are used as an indicator of NUE since it is difficult to evaluate the amount of plant-available $\mathrm{N}$ from the soil or any source of $\mathrm{N}$ inputs, including fertilizer application and N fixation [183]. Genotypes with high NUE are those cultivars that produce high grain yields with the application of $\mathrm{N}$, while those that do not yield well are genotypes with low NUE. Cultivars with high NUE have the ability to take up N and efficiently use it to produce grains [184]. The relative weight of root, shoot and plant under two different $\mathrm{N}$ treatments could reveal the cultivars showing tolerance of low $\mathrm{N}$ stress. The QTLs identified for relative performance were distinctive from those for root, shoot and plant weight detected under the two $\mathrm{N}$ treatment conditions [182].

The study of Tong et al. [174] revealed a correlation with path analysis indicating that spikelet fertility percentage had the most significant contribution to grain yield per plant at the 300-and 150-kg urea ha ${ }^{-1}$ rates, but filled grains per panicle contributed a strong positive relationship with grain yield per plant at the N0 level. Six of 15 QTLs identified with main effects were detected for each trait except SFP. Clusters of main-effect QTLs associated with several key traits were observed on chromosomes 1, 2, 3, 5, 7 and 10, respectively. The main-effect QTLs ( $q$ GYPP-4b and $q G N P P-12$ ) were identified at the N0 rate only, which explained $10.9 \%$ and $10.2 \%$ of the total phenotypic variation explained (PVE). The identification of genomic regions associated with yield and its components at different nitrogen rates will be useful in marker-assisted selection for improving the NUE of rice. The NUE-related trait in rice is so complex that different results were obtained in previous publications because of various experimental conditions, methods and materials. The main-effect QTL (M-QTL), epistatic QTL $(E-Q T L)$ and QTL $\times$ environment $(\mathrm{Q} \times \mathrm{E})$ interactions of six traits were investigated using a fully-saturated simple sequence repeat (SSR) linkage map. Obara et al. [185] found a QTL region associated with panicle number and panicle weight on chromosome 2 that contains a regulator gene (GS1) for glutamine synthetase activity. The selected rice plants based on this QTL region showed superiority in tillering ability, panicle number and total panicle weight under low $\mathrm{N}$ rates.

Several researchers identified main-effect QTLs on chromosome 3 [171], chromosome 6 [186] and chromosomes 2 and 9 [170] by using doubled haploids and Recombinant Inbred Lines (DHs and RILs) populations.

Among these QTLs, one QTL was identified as being associated with the number of grains per panicle under low $\mathrm{N}$ rate, and it was located in a similar region to the Pup1 locus on chromosome 12, thus encouraging the use of Pup1 materials for testing low-N tolerance [5]. Recently, in a hydroponic experiment with CSSLs, Zhou et al. [118] identified a total 23 QTLs, with seven QTLs for N uptake (NUP) located on different chromosomes (2, 3, 6, 8, 10 and 11), with phenotypic variation (PV) ranging from 3.16-13.99\%. Six QTLs for N use efficiency were located on chromosomes 2, 4, 6 and 10 and had explained PV ranging from 3.76-12.34\%, respectively. The remaining 10 QTLs were responding to grain yield (GY) and biomass yield (BY). With the results of correlation analysis, Zhou et al. [118] suggested that both NUP and NUE had large effects on grain yield. Previous reports of Dong et al. $[187,188]$ showed the NUP trait more closely associated with grain yield than NUE. NUE and NUP trait-linked QTLs are highly useful for improving grain yield under low-input conditions.

\subsection{Phosphorus Use Efficiency and Related QTLs}

Phosphorus is one of the essential macro-nutrients required for plant growth and development. Low availability of phosphorus in a variety of soils, especially in the tropics, often limits rice grain yields [189], along with the lack of available P sources locally in many countries. The higher importation and transportation costs of $\mathrm{P}$ fertilizers frequently prevent resource-poor farmers, especially in developing countries, from applying $\mathrm{P}$ to their deficient farmlands. Thus, developing rice cultivars 
with improved tolerance of $\mathrm{P}$ deficiency may therefore be a cost-effective solution to this problem. Rose and Wissuwa [45], optimistic that breeding for poor soil with high P uptake and high PUE needs to be developed and to maximize crop grain yield in such low-input systems, noticed that continuous cropping of poor soil is often related to poverty. It is also important to breed efficient crops. A combination of both $\mathrm{P}$ uptake and $\mathrm{P}$ internal nutrient efficiency is equally desirable for high-input systems, whereas it would facilitate a reduction in fertilizer rates without yield compensation. Dobermann and Fairhurst [190] reported in rice that P fertilizer use efficiency is only $\sim 25 \%$, which suggests considerable scope for improvement.

Several researchers have identified genes and QTLs governing agronomic traits related to nutrient use efficiency, and these are shown in Tables 1 and 2 and are represented in Figure 2 with the respective NPK QTLs located on 12 chromosomes associated with morpho-physiological traits under low-input conditions. The Pup1 gene responsible for phosphorus uptake was identified and characterized by Chin et al. [57] (Table 1). Quantitative trait loci for P deficiency tolerance were identified in a rice population derived from a cross between P-inefficient japonica cultivar Nipponbare and P-efficient indica landrace Kasalath [65]. Tolerance of $\mathrm{P}$ deficiency was primarily caused by genotypic differences in P uptake; internal PUE had a negligible effect, and even phosphorus content changed slightly within $72 \mathrm{~h}$ in the shoots under low phosphorus stress, but phosphorus content decreased rapidly at $24 \mathrm{~h}$ in the roots [62].

Several studies were carried out to understand the genetics of tolerance of phosphorus deficiency in crops, and they identified several QTLs associated with it [54-66,154,156,191]. Su et al. [192] reported that 39 QTLs were associated with panicle number and weight of dry matter, chosen as the indices of $P$ deficiency tolerance in wheat (Triticum aestivum L.).

The QTLs related to root traits, panicle number and seed set percentage were reported in rice $[66,153,156]$. Yield component traits such as panicle number and seed-setting percentage could be used as selection indices for $P$ deficiency tolerance in rice [192]. However, only a few reports are available for the QTL mapping of grain yield and its components for $P_{-}$deficiency tolerance.

A significant QTL for P uptake was mapped to a 13.2-cM interval on the long arm of chromosome 12 flanked by markers C443-G2140. The position was estimated to be at 54.5-cM, a 3-cM distance from marker C443. Additional minor QTLs were found on chromosomes 2, 6 and 10 [155]. However, the first evidence supporting the presence of a significant QTL for $\mathrm{P}_{-}$deficiency tolerance came from a study by Ni et al. [154].

A doubled-haploid population was derived from a cross between $P_{-}$deficiency-tolerant japonica rice IRAT109 and P deficiency-sensitive japonica rice Yuefu [193]. A total of 116 lines were evaluated for yield per plant and its component traits under P deficiency and normal conditions. There were significant differences in seed-setting percentage, panicle number per plant and yield per plant for the doubled haploid DH population between the two conditions, whereas there was no significant difference in 1000-grain weight and grain number per panicle. The results indicated that seed-setting percentage, panicle number per plant and yield per plant were easily influenced by $\mathrm{P}_{-}$deficiency. Restricted fragment length polymorphism (RFLP) and simple sequence repeat (SSR) markers were used to cover 1535-cM of the rice genome to discover a total of 17 QTLs for plant yield and its components (1000-grain weight, seed-setting \%, panicle number per plant, grain number per panicle) under P deficiency conditions. These QTLs explained from $2.65-20.78 \%$ of the phenotypic variance, with 12 QTLs showing higher than $10 \%$. For 1000-grain weight, one QTL was detected, which had an logarithm of the odds LOD score of 5.13 and high contribution of PV (14.38\%). Five QTLs were linked with seed-setting percentage, and three QTLs were linked with panicle number per plant [193]. Out of these five, three SP QTLs ( $q S P 2, q S P 5$ and $q S P 11$ ) contributed more than $10 \%$, and the three QTLs for panicle number per plant had high general contributions of more than $17 \%$. Two QTLs ( $q P N 10$ and $q P N 12$ ) had an opposite additive effect. For grain number per panicle, four QTLs were detected, two of which ( $q$ GN6 and $q G N 7$ ) had high general contributions and positive effects. Four additive QTLs were found on chromosomes 2, 3, 6 and 7, which explained $4.77-13.55 \%$ of the phenotypic 
variance, for yield per plant. Three of them, $q Y P 3, q Y P 6$ and $q Y P 7$, had high general contributions of more than $10 \%$ [194].

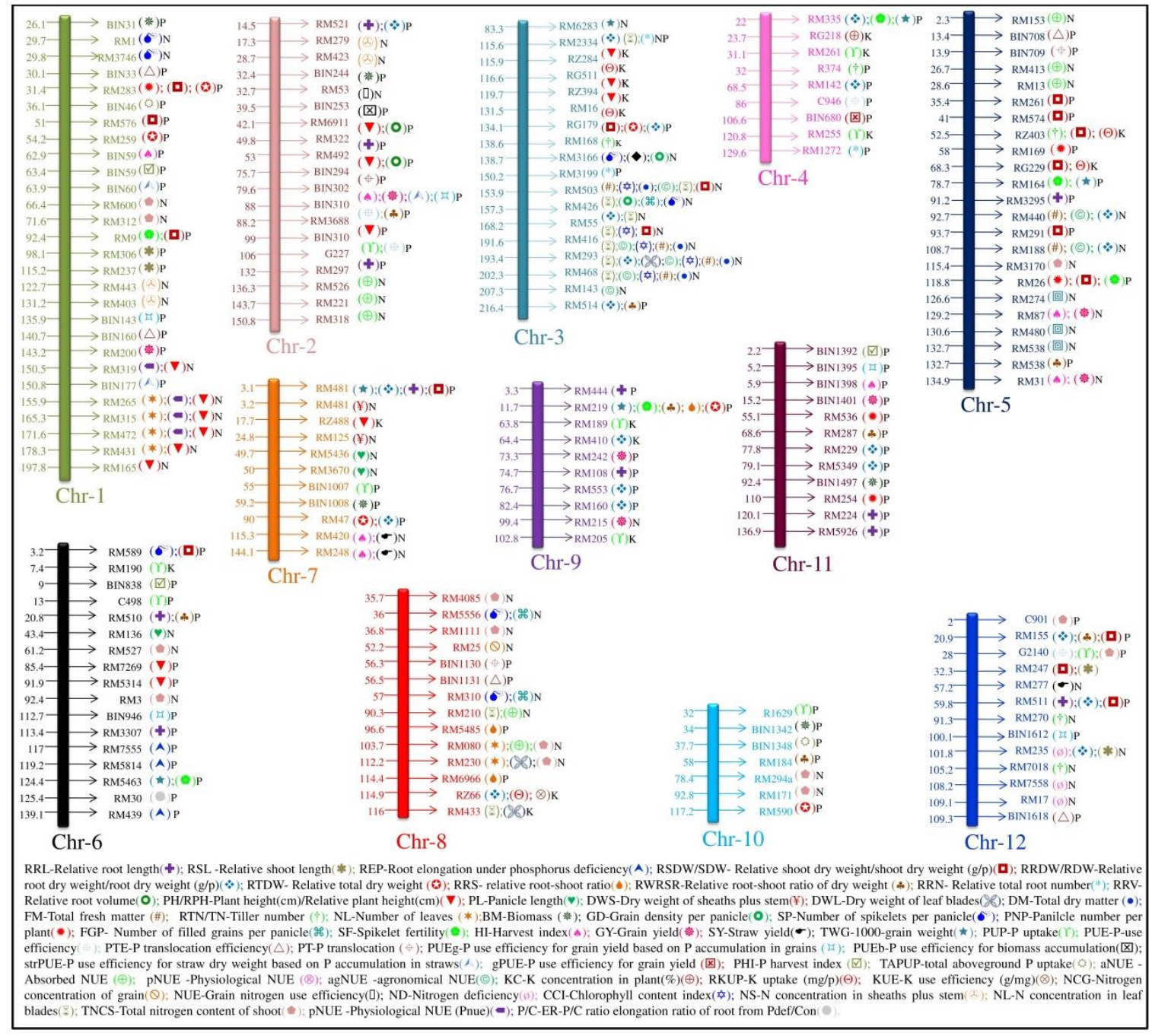

Figure 2. Diagram of 12 chromosomes with reported nutrient use efficiency (NuUE)-NPK QTLs linked to markers associated with the respective traits were identified through marker assisted selection (MAS) breeding approaches in a low-NPK environment using diverse mapping populations of rice.

\subsection{Potassium Use Efficiency and Related QTLs}

Among the essential elements, potassium is necessary for plant growth. It is the activator of many enzymes in plants and the osmotic regulator of cell solute potential, and it plays a significant role in plant growth and metabolism. In rice, increased application of $\mathrm{K}$ fertilizer significantly improves grain and milling quality, such as increasing the percentages of brown rice, milled rice and head milled rice; reducing chalkiness; and enhancing grain protein content [194]. Fageria et al. [101] reported on K uptake and the use efficiency of upland rice under Brazilian conditions. They conducted a greenhouse experiment with the $\mathrm{K}$ rate as zero (natural soil level) and $200 \mathrm{mg} \mathrm{K} \mathrm{kg}^{-1}$ of soil with the objective of evaluating the influence of $K$ on grain yield, $K$ uptake and their use efficiency, especially for six upland rice genotypes grown on a Brazilian Oxisol. Shoot dry weight and grain yield were significantly influenced by $\mathrm{K}$ rate and genotype treatments. The potassium concentration in the shoot was about six-fold greater than that of the grain, across two $\mathrm{K}$ rates and six genotypes. However, the $\mathrm{K}$ use efficiency ratio (KUER) was about 6.5-times higher in the grain than in the shoot, over two K rates and six genotypes. Potassium uptake in shoot and grain and KUER were significantly and positively 
associated with grain yield. Besides these, soil Ca, K, base saturation, acidity saturation, Ca saturation, $\mathrm{K}$ saturation, $\mathrm{Ca} / \mathrm{K}$ ratio and $\mathrm{Mg} / \mathrm{K}$ ratio showed a significant influence on the $\mathrm{K}$ application rate.

A greenhouse experiment was conducted at four levels of saline water irrigation (tap water and 2, 4 and $6 \mathrm{dS} \mathrm{m}^{-1}$ of salinity) and four different methods of $\mathrm{K}$ application (spraying with distilled water as the control, application of potassium on soil, potassium spraying and application of potassium on soil plus spraying). The purpose was to study the efficiency of potassium spraying and use in the soil and their effect on yield and its components under salinity stress. The results showed that grain yield, number of shoots, 100-seed weight, tiller number, dry root weight and K uptake in seeds and shoots decreased significantly with increasing salinity. The best method of $\mathrm{K}$ application was soil intake plus spraying [195]. In an investigation of a DH population consisting of 123 lines derived from indica variety IR64 and japonica variety Azucena under a hydroponic experiment, Wu et al. [177] identified three QTLs associated with shoot and root dry weight under K-deficient conditions. These same three QTLs were also influencing the effect on $\mathrm{K}$ content in the plant $(\mathrm{KC}), \mathrm{K}$ uptake and $\mathrm{K}$ use efficiency. The QTLs individually had PVE ranging from $8-15 \%$ and were positioned on chromosomes 2, 3, 5 and 8 in K_ deficiency conditions.

\section{Effect of Nutrient Use Efficiency across Medium- and Long-Duration Rice}

Singh et al. [6] assessed the variability in grain yield and $\mathrm{N}$ use of 10 medium-duration (119 \pm 4 days after seeding) and 10 long-duration (130 \pm 4 DAS) genotypes. These genotypes showed varying rates of acquisition and use of soil and fertilizer N. Significant diversity within genotypes was found in grain yield and $\mathrm{N}$ uptake, efficiency and partitioning parameters (physiological $\mathrm{N}$ use efficiency, agronomic $\mathrm{N}$ use efficiency, apparent recovery, partial factor productivity (PFP) of applied $\mathrm{N}, \mathrm{N}$ productivity index and $\mathrm{N}$ harvest index). The $\mathrm{N}$ use-efficient genotypes were IR54790-B-B-38, BG380-2 and BG90-2 (medium duration) and IR3932-182-2-3-3-2, IR54853-B-B-318 and IR29723-88-2-3-3 (long duration), producing high grain yields at both low and high rates of $\mathrm{N}$, whereas inefficient genotypes produced low grain yields at low $\mathrm{N}$ rates, but responded well to $\mathrm{N}$ application. Increases in grain yields were highly correlated with $\mathrm{N}$ uptake. The grain yield-N uptake relationship for individual genotypes indicated significant differences in slope and the grain yield obtained with soil N (GY0). Significant differences in GY0 were due to genotypic variation in N uptake and efficiency of use. The $\mathrm{N}$ harvest index was related to both $\mathrm{N}$ uptake and use efficiency. The $\mathrm{N}$ productivity index, which integrated both GY0 and PFP of applied N, provided a better ranking of rice genotypes. The performance levels of efficient and inefficient genotypes over a range of soil and fertilizer $\mathrm{N}$ supply were consistent across three seasons of trials.

\section{QTLs for Both Low Nitrogen and Phosphorus Stress}

Eight QTLs explained panicle number per plant under the three treatments. Five of the QTLs were identified under the low-nitrogen treatment, and three were identified under the low-phosphorus treatment. The alleles from Nipponbare at all the QTLs_ had adverse effects on panicle number (decreasing it by 42.6-62.9\%). No common QTLs were identified for panicle number under both low-N and low-P stresses. A total of 18 QTLs for yield per plant were detected in three treatments [175]. Located on chromosome 4, a QTL $(Q y d-4 c)$ was identified in all treatments with relatively higher phenotypic variance explained (58.2\%, 55.2\% and $88.1 \%$ ) under normal, low-N and low-P conditions, respectively. The authors detected another four QTLs (Qyd-3a, Qyd-4a, Qyd-7a and Qyd-10) in two treatments. The rest of the 13 QTLs were identified in only low-nitrogen or low-phosphorus treatments. Regarding relative yield, two and three QTLs were identified in different N and P treatments, respectively, of which Qryd-7a was a common QTL, suggesting that the CSSL containing the Qryd-7a locus was sensitive to both $\mathrm{N}_{\text {and }} \mathrm{P}_{-}$deficiency stresses [127,172]. QTL Qyd-4a was located in the same chromosomal region as the QTL for dry weight of seedling root [167]. The authors conjectured this substitution region to be associated with root response to nutrient stresses, probably containing genes for regulating nutrient absorption and consequently affecting yield per plant in 
rice. Root elongation gets hit by either $\mathrm{N}$ or $\mathrm{P}_{-}$deficiency $[126,167,172]$, resulting in various nutrition assimilation in plants. Several QTLs from this study correspond to known genes in the $\mathrm{N}$ or P metabolic pathway. For example, $Q y d-2 b$ for $N_{-}$deficiency tolerance was located near the gene encoding cytosolic glutamine synthetase (GS1), and $Q y d-3 b$ and $Q p n-3$ were nearby the genes for glutamate dehydrogenase (GDH2) [182]. Furthermore, Qyd-12 was detected only under low-P conditions, and it co-localized with a significant QTL (Pup1) on chromosome 12, which was involved in P absorption [154]. These results indicate that the QTLs specifically detected under single $\mathrm{N}$ or $\mathrm{P}_{-}$deficiency conditions may be involved in different pathways of $\mathrm{N}$ and $\mathrm{P}$ metabolism. Their tightly linked markers have breeding potential in pyramiding elite QTLs for $\mathrm{N}$ and $\mathrm{P}$ use efficiency.

Tolerance of low nitrogen stress conditions is a highly desired characteristic for sustainable crop production. The genetic components associated with low $\mathrm{N}$ tolerance in rice at the seedling stage, including main QTL effects, epistatic QTL effects and QTL by environment interactions, using a population of 239 RILs derived from a cross between popular Zhenshan 97 and Minghui 63, were studied [182] in solution culture. Root, shoot and plant weight over two N treatments were measured and the relative weight of the two treatments for each trait considered as measurements for low-N tolerance. Four to eight QTLs with main effects were detected for each of the nine traits. Very few QTLs were detected in both low and normal nitrogen conditions, and interestingly, most of the QTLs for the relative measurements were distinct from those for traits under the two nitrogen treatments, indicating very little commonality in the genetic basis of the traits and their relative performance under low and normal nitrogen conditions. In rice, some agronomic traits involving effective tiller number, spikelet fertility percentage and grain yield were studied under low nitrogen stress $[166,170,185,196]$. Two main-effect QTLs with large contribution rates were detected at the N0 rate. One of them affecting grain number per plant was detected at the interval RM117-RM101 on chromosome 12 , accounting for $10.2 \%$ of the total phenotypic variance. There was no significant interaction between this M-QTL and environmental factors. This QTL is from the same region as a QTL (Pup1) related to phosphorus uptake [156]. Zhao et al. [33] reported that single segment substitution lines (SSSLs) each having a single chromosome segment derived from a donor under the same genetic background as the recipient parent were developed in rice by advanced backcrossing and genome-assisted selection. The QTLs for 22 essential traits were detected in rice with 32 SSSLs by a randomized block design in two to four cropping seasons. However, the QTLs controlling grain weight, grain length, the ratio of grain length to width and heading date were relatively stable. Fifty-nine QTLs were detected and distributed on chromosomes 1, 2, 3, 4, 6, 7, 8, 10 and 11, of which 18 were detected more than twice. Only $30.5 \%$ of the QTLs were repeatedly identified across different cropping seasons. Mostly the QTLs governing important agronomic traits showed small additive effects and instability. The stable QTLs usually had larger additive effects and were less affected by environment. With recent successful achievements in the Green Super Rice (GSR) project, efforts were made for highly adaptive rice cultivars with higher grain yield under low-input conditions [13,196-201]. About a 10\% yield increase was obtained in elite GSR rice cultivars as compared with the local check variety NSIC Rc222 under multiple abiotic stress tolerance and low-input conditions, without compromising grain yield and quality [200]. Further progress in the genetic regulation of NuUE of GSR cultivars may provide valuable materials to understand the molecular and physiological pathways for the improvement of yield and grain quality under low-input conditions.

\section{Agronomic Efficiency and Partial Factor Productivity QTLs}

There is a significant increase in grain yield for each $\mathrm{kg}$ of fertilizer applied, termed agronomic efficiency (AE). Efficient fertilizer use is defined as maximum returns per unit of fertilizer applied [202]. According to Yadav [202], PFP and AE are useful measures of NUE, as they provide a basis for an integrative index that quantifies total economic output relative to the use of all nutrient resources in the system. Cassman et al. [203] defined PFP and AE to increase by increasing the amount, uptake and 
use of available nutrients and further by increasing the efficiency of applied nutrients that are taken up by the crop and used to produce grain.

Several researchers have studied AE and PFP in rice and other cereal crops. Dobermann [204] reported cereal crops in terms of $\mathrm{AE}$ of $10-30 \mathrm{~kg}_{\text {grain kg }}^{-1} \mathrm{~N}$, where $>30 \mathrm{~kg}_{\text {grain kg }}^{-1}$ is found in a well-managed system or at a low rate of $\mathrm{N}$ use or low soil $\mathrm{N}$ supply and for PFP $40-70 \mathrm{~kg}_{\text {grain }} \mathrm{kg}^{-1} \mathrm{~N}$, with $>70 \mathrm{~kg}^{-1}$ at low rates of $\mathrm{N}$ or in a well-managed efficient system. Wen-xia et al. [205] reported $\mathrm{AE}$ in two kinds of rice, one being Jinzao, with AE ranging from $8.02-20.14 \mathrm{~kg}_{\text {grain }} \mathrm{kg}^{-1} \mathrm{~N}$, and the second one being Shanyou63, with an AE range of 3.4-18.37 kg grain $\mathrm{kg}^{-1} \mathrm{~N}$ absorbed. Yoshida [206]) estimated AE to be 15-25 $\mathrm{kg}_{\text {grain }} \mathrm{kg}^{-1} \mathrm{~N}$, and Cassman et al. [203] reported AE at $15-20 \mathrm{~kg}$ grain $\mathrm{kg}^{-1} \mathrm{~N}$ in the dry season in farmers' fields in the Philippines.

Amanullah et al. [207] declared that in maize, PFP for applied $\mathrm{N}$ was $36.62 \mathrm{~kg}_{\text {grain }} \mathrm{kg}^{-1} \mathrm{~N}$ and AE for applied $\mathrm{N}$ was $22.49 \mathrm{~kg}_{\text {grain }} \mathrm{kg}^{-1} \mathrm{~N}$, using DAP and SSP in the field for the AE of two fertilizer applications, resulting in 13.01 and $13.71 \mathrm{~kg}$ grain $\mathrm{kg}^{-1} \mathrm{P}$, and PFP resulting in 63.58 and $61.92 \mathrm{~kg}_{\text {grain }} \mathrm{kg}^{-1} \mathrm{P}$. Rao [208] reported AE for applied K in hybrid cotton to be $8.8 \mathrm{~kg}_{\text {grain }} \mathrm{kg}^{-1} \mathrm{~K}$, where the application rate of the fertilizer is NPK at 200-150-100 $\mathrm{kg} \mathrm{ha}^{-1}$, and for non-hybrid cotton, $5.9 \mathrm{~kg}$ grain $\mathrm{kg}^{-1} \mathrm{~K}$ at the same rate of fertilizer application. In hybrid rice, AE for applied $\mathrm{P}$ was $5.2 \mathrm{~kg}$ grain $\mathrm{kg}^{-1} \mathrm{P}$ and $11.8 \mathrm{~kg}_{\text {grain }} \mathrm{kg}^{-1} \mathrm{~K}$ with a fertilizer application rate of NPK of 200-75-200 and 200-150-200 kg ha ${ }^{-1}$, respectively. The AE for applied P in non-hybrid rice was $2.3 \mathrm{~kg}_{\text {grain }} \mathrm{kg}^{-1} \mathrm{P}$ and $4.7 \mathrm{~kg}_{\text {grain }} \mathrm{kg}^{-1} \mathrm{P}$, where the fertilizer rate was the same. Rao [208] in another study showed that only the application of $\mathrm{P}\left(\mathrm{N}\right.$ and $\mathrm{K}$ as blanket doses) gave $\mathrm{AE}$ for non-hybrid rice of $4.2-15.6 \mathrm{~kg}$ grain $\mathrm{kg}^{-1} \mathrm{P}$ and $5.9-11.4 \mathrm{~kg}_{\text {grain }} \mathrm{kg}^{-1} \mathrm{P}$, where the $\mathrm{P}$ application rate was 75 and $150 \mathrm{~kg} \mathrm{ha}^{-1}$ and plant spacing was $12.5 \times 10 \mathrm{~cm}$ and $10 \times 10 \mathrm{~cm}$, respectively.

The application of a unit of fertilizer is economical if the increase in crop yield due to the quantity of fertilizer added is higher than the cost of the fertilizer used. However, if a unit of fertilizer does not increase the grain yield enough to pay for its cost, then its application will not be considered economical and will not be profitable even after a constant increase in grain yield [209]. The application of essential plant nutrients in optimum split dosages and proportion, dispensed to plants in an appropriate method and timing, is the key to increased and sustained crop production.

\section{Conclusions}

Improving global rice yield productivity under low-input conditions is the main challenge for plant breeders and molecular biologists to develop/improve appropriate rice cultivars. Improving NuUE (nutrient use efficiency) is a key component from an agronomic, economic and environmental viewpoint. Despite the highly complex nature of NuUE in rice, recent trends in molecular marker-assisted selection and advanced biotechnological tools can accelerate the dissecting of the polygenic nature of complex traits. Apart from several breeding and agronomic strategies, balanced $\mathrm{N}, \mathrm{P}$ and $\mathrm{K}$ nutrient elements are required to maintain soil fertility, uptake and transportation from soil to grain to produce higher grain yield with nutrient quality traits. The combined genomic and phenomic studies are valuable to distinguish the QTL and gene responses to NPK acquisition and transportation identified, and very few of them are strongly used with the target trait of interest in plant breeding programs. So far, plenty of QTLs have been identified in diverse genetic backgrounds with significant PVE under different treatment doses of NPK. By using this QTL information, better NuUE genotypes can be developed suitable for resource-poor farmers. Further, by employing these rapid developments, an integrative SNP array with innovative techniques such as Next-generation sequencing (NGS) and Genotyping by sequencing (GBS )technologies, high-density and SNP linkage maps and molecular breeding approaches are feasible solutions for identifying cultivars with superior NuUE by incorporating them into breeding cycles and understanding the molecular genetics and physiological mechanisms of N, P and K status in plants under different fertilizers or deficiency conditions. However, a combined holistic approach requires different aspects of work in the pipeline and omic technologies for its implementation in modern NuUE breeding programs. 
Author Contributions: J.A., Z.A.J. and A.M. worked on outlining the contents in the manuscript and prepared the draft article. A.A., A.M., J.A. and Z.L. contributed to the screening methodologies associated with aspects of molecular and genomic regions. J.A. and Z.L. conceived of the basic idea, gave suggestions, corrected the entire article and improved the prospects for breeding programs. All the authors read and approved the review article.

Acknowledgments: The authors would like to thank and acknowledge the Bill \& Melinda Gates Foundation (BMGF) for providing a research grant to Z.L. for the Green Super Rice project under ID OPP1130530. We would also like to thank the Department of Agriculture (DA) of the Philippines for providing funds to J.A. under the Next-Gen project.

Conflicts of Interest: The authors declare that the research review was conducted in the absence of any commercial or economic associations that could be construed as a potential conflict of interest.

\section{References}

1. Ladha, J.K.; Pathak, H.; Krupnik, T.J.; Six, J.; Kessel, C.V. Efficiency of fertilizer nitrogen in cereal production: Retrospects and prospects. Adv. Agron. 2005, 87, 85-156.

2. Xu, X.; Liu, X.; He, P. Yield Gap, Indigenous Nutrient Supply and Nutrient Use Efficiency for Maize in China. PLoS ONE 2015, 10, e0140767. [CrossRef] [PubMed]

3. Roberts, T.L. Improving Nutrient Use Efficiency. Turk. J. Agric. For. 2008, 32, 177-182.

4. Liu, Z.; Zhu, C.; Jiang, Y.; Tian, Y.; Yu, J.; An, H.; Tang, W.; Sun, J.; Tang, J.; Chen, G.; et al. Association mapping and genetic dissection of nitrogen use efficiency-related traits in rice (Oryza sativa L.). Funct. Integr. Genom. 2016, 16, 323-333. [CrossRef] [PubMed]

5. Vinod, K.K.; Heuer, S. Approaches towards nitrogen- and phosphorus-efficient rice. AoB Plants 2012, 28, 1-18. [CrossRef] [PubMed]

6. Singh, U.; Ladha, J.K.; Castillo, E.G.; Punzalam, G.; Tirol-Padre, A.; Duqueza, M. Genotypic variation in nitrogen use efficiency in medium and long-duration rice. Field Crops Res. 1998, 58, 35-53. [CrossRef]

7. Han, M.; Okamoto, M.; Beatty, P.H.; Rothstein, S.J.; Good, A.G. The Genetics of Nitrogen Use Efficiency in Crop Plants. Annu Rev. Genet. 2015, 49, 269-289. [CrossRef] [PubMed]

8. Van Bueren, E.T.L.; Struik, P.C. Diverse concepts of breeding for nitrogen use efficiency, a review. Agron. Sustain. Dev. 2017, 37, 50. [CrossRef]

9. Chen, H.; Xie, W.; He, H.; Yu, H.; Chen, W.; Li, J.; Yu, R.; Yao, Y.; Zhang, W.; He, Y.; et al. A high-density SNP genotyping array for rice biology and molecular breeding. Mol. Plant 2014, 7, 541-553. [CrossRef] [PubMed]

10. Thomson, M.J.; Singh, N.; Dwiyanti, M.S.; Wang, D.R.; Wright, M.H.; Perez, F.A.; DeClerck, G.; Chin, J.H.; Malitic-Layaoen, G.A.; Juanillas, V.M.; et al. Large-scale deployment of a rice 6 K SNP array for genetics and breeding applications. Rice 2017, 10, 40. [CrossRef] [PubMed]

11. Feng, B.; Chen, K.; Cui, Y.; Wu, Z.; Zheng, T.; Zhu, Y.; Ali, J.; Wang, B.; Xu, J.; Zhang, W.; et al. Genetic Dissection and Simultaneous Improvement of Drought and Low Nitrogen Tolerances by Designed QTL Pyramiding in Rice. Front. Plant Sci. 2018, 9, 306. [CrossRef] [PubMed]

12. Baligar, V.C.; Fageria, N.K.; Hea, Z.L. Nutrient Use Efficiency in Plants. Commun. Soil Sci. Plant Anal. 2001, 32, 7-8. [CrossRef]

13. Ali, J.; Xu, J.L.; Gao, Y.M.; Fontanilla, M.A.; Li, Z.K. Green super rice (GSR) technology: An innovative breeding strategy-achievements \& advances. In Proceedings of the 12th SABRAO Congress-Plant Breeding towards 2025: Challenges in a Rapidly Changing World, Chiang Mai, Thailand, 13-16 January 2012; pp. 16-17.

14. Kole, C.; Muthamilarasan, M.; Henry, R.; Edwards, D.; Sharma, R.; Abberton, M.; Batley, J.; Bentley, A.; Blakeney, M.; Bryant, J.; et al. Application of genomics-assisted breeding for generation of climate resilient crops: Progress and prospects. Front. Plant Sci. 2015, 6, 563. [CrossRef] [PubMed]

15. Stein, J.C.; Yu, Y.; Copetti, D.; Zhang, L.; Zhang, C.; Chougule, K.; Gao, D.; Iwata, A.; Goicoechea, J.L.; Wei, S.; et al. Genomes of 13 domesticated and wild rice relatives highlight genetic conservation, turnover and innovation across the genus Oryza. Nat. Genet. 2018, 50, 285-296. [CrossRef] [PubMed]

16. Broadbent, F.E.; De Datta, S.K.; Laureles, E.V. Measurement of nitrogen utilization efficiency in rice genotypes. Agron. J. 1987, 79, 786-791. [CrossRef]

17. Singh, U.; Cassman, K.G.; Ladha, J.K. Innovative Nitrogen Management Strategies for Lowland Rice Systems; Fragile Lives in Fragile Ecosystems, International Rice Research Institute, P.O. Box 933: Manila, Philippines, 1995; pp. 229-254. 
18. Xiao, J.H.; Li, J.M.; Yuan, L.P.; Yuan, S.R. Identification of QTLs affecting traits of agronomic importance in a recombinant inbred population derived from a sub-specific rice cross. Theor. Appl. Genet. 1996, 92, 230-244. [CrossRef] [PubMed]

19. Wisser, R.J.; Sun, Q.; Hulbert, S.H.; Kresovich, S.; Nelson, R.J. Identification and Characterization of Regions of the Rice Genome Associated with Broad-Spectrum, Quantitative Disease Resistance. Genetics 2015, 169, 2277-2293. [CrossRef] [PubMed]

20. Bocianowski, J. Epistasis interaction of QTL effects as a genetic parameter influencing estimation of the genetic additive effect. Genet. Mol. Biol. 2013, 36, 93-100. [CrossRef] [PubMed]

21. Zhu, H.; Liu, Z.; Fu, X.; Dai, Z.; Wang, S.; Zhang, G.; Zeng, R.; Liu, G. Detection and characterization of epistasis between QTLs on plant height in rice using single segment substitution lines. Breed. Sci. 2015, 65, 192-200. [CrossRef] [PubMed]

22. Li, Z.S.; Pinson, R.M.; Stansel, J.W.; Park, D. Identification of two major genes and quantitative trait loci (QTLs) for heading date and plant height in cultivated rice (Oryza sativa L.). Theor. Appl. Genet. 1995, 91, 371-381. [CrossRef] [PubMed]

23. Kang, H.J.; Cho, Y.G.; Tlee, Y.; Eun, M.Y.; Shim, J.U. QTL mapping of genes conferring days to heading, culm length and panicle length based on molecular map of rice (Oryza sativa L.). RDA J. Crop Sci. 1998, 40, 55-61.

24. Yamamoto, T.; Yonemaru, J.; Yano, M. Towards the Understanding of Complex Traits in Rice: Substantially or Superficially? DNA Res. 2009, 16, 141-154. [CrossRef] [PubMed]

25. Zhao, K.; Tung, C.W.; Eizenga, G.C.; Wright, M.H.; Ali, M.L.; Price, A.H.; Norton, G.J.; Islam, M.R.; Reynolds, A.; Mezey, J.; et al. Genome-wide association mapping reveals a rich genetic architecture of complex traits in Oryza sativa. Nat. Commun. 2011, 2, 467. [CrossRef] [PubMed]

26. Nongpiur, R.C.; Singla-Pareek, S.L.; Pareek, A. Genomics Approaches for Improving Salinity Stress Tolerance in Crop Plants. Curr. Genom. 2016, 17, 343-357. [CrossRef] [PubMed]

27. Nguyen, H.T.T.; Dang, D.T.; Pham, C.V.; Bertin, P. QTL mapping for nitrogen use efficiency and related physiological and agronomical traits during the vegetative phase in rice under hydroponics. Euphytica 2016, 212, 473-500. [CrossRef]

28. Wang, H.; Qin, F. Genome-Wide Association Study Reveals Natural Variations Contributing to Drought Resistance in Crops. Front. Plant Sci. 2017, 30, 1110. [CrossRef] [PubMed]

29. Yadav, M.K.; Aravindan, S.; Ngangkham, U.; Subudhi, H.N.; Bag, M.K.; Adak, T.; Munda, S.; Samantary, S.; Jena, M. Correction: Use of molecular markers in identification and characterization of resistance to rice blast in India. PLoS ONE 2017, 12, e0179467. [CrossRef] [PubMed]

30. Flint-Garcia, S.A.; Thuillet, A.C.; Yu, J.; Pressoir, G.; Romero, S.M.; Mitchell, S.E.; Doebley, J.; Kresovich, S.; Goodman, M.M.; Buckler, E.S. Maize association population: A high-resolution platform for quantitative trait locus dissection. Plant J. 2005, 44, 1054-1064. [CrossRef] [PubMed]

31. Ersoz, E.S.; Yu, J.; Buckler, E.S. Applications of linkage disequilibrium and association mapping in maize. Mol. Genet. Approach Maize Improv. 2009, 63, 173-195.

32. Clark, R.M.; Schweikert, G.; Toomajian, C.; Ossowski, S.; Zeller, G.; Shinn, P.; Warthmann, N.; Hu, T.T.; Fu, G.; Hinds, D.A.; et al. Common sequence polymorphisms shaping genetic diversity in Arabidopsis thaliana. Science 2007, 317, 338-342. [CrossRef] [PubMed]

33. Zhao, F.M.; Zhu, H.T.; Ding, X.H.; Zeng, R.Z.; Zhang, Z.L.; Zhang, G. Detection of QTLs for Important Agronomic Traits and Analysis of Their Stabilities Using SSSLs in Rice. Agric. Sci. China 2007, 6, 769-778. [CrossRef]

34. Goff, S.A.; Ricke, D.; Lan, T.H.; Presting, G.; Wang, R.; Dunn, M.; Glazebrook, J.; Sessions, A.; Oeller, P.; Varma, H.; et al. A draft sequence of the rice genome (Oryza sativa L. ssp japonica). Science 2002, 296, 92-100. [CrossRef] [PubMed]

35. Yu, J.; Hu, S.; Wang, J.; Wong, G.K.; Li, S.; Liu, B.; Deng, Y.; Dai, L.; Zhou, Y.; Zhang, X.; et al. A draft sequence of the rice genome (Oryza sativa L. ssp indica). Science 2002, 296, 79-92. [CrossRef] [PubMed]

36. Du, H.; Yu, Y.; Ma, Y.; Gao, Q.; Cao, Y.; Chen, Z.; Ma, B.; Qi, M.; Li, Y.; Zhao, X.; et al. Sequencing and de novo assembly of a near complete indica rice genome. Nat. Commun. 2017, 8, 15324. [CrossRef] [PubMed]

37. McNally, K.L.; Childs, K.L.; Bohnert, R.; Davidson, R.M.; Zhao, K.; Ulat, V.J.; Zeller, G.; Clark, R.M.; Hoen, D.R.; Bureau, T.E.; et al. Genome wide SNP variation reveals relationships among landraces and modern varieties of rice. Proc. Natl. Acad. Sci. USA 2009, 106, 12273-12278. [CrossRef] [PubMed] 
38. Huang, X.; Wei, X.; Sang, T.; Zhao, Q.; Feng, Q.; Zhao, Y.; Li, C.; Zhu, C.; Lu, T.; Zhang, Z.; et al. Genome wide association studies of 14 agronomic traits in rice landraces. Nat. Genet. 2010, 42, 961-967. [CrossRef] [PubMed]

39. Ebana, K.; Yonemaru, J.; Fukuoka, S.; Iwata, H.; Kanamori, K.; Namiki, N.; Nagasaki, H.; Yano, M. Genetic structure revealed by a whole-genome single nucleotide polymorphism survey of 5 diverse accessions of cultivated Asian rice (Oryza sativa L.). Breed. Sci. 2010, 60, 390-397. [CrossRef]

40. Zhao, K.; Aranzana, M.J.; Kim, S.; Lister, C.; Shindo, C.; Tang, C.; Toomajian, C.; Zheng, H.; Dean, C.; Marjoram, P.; et al. An Arabidopsis example of association mapping in structured samples. PLoS Genet. 2007, 3, e4. [CrossRef] [PubMed]

41. Agrama, H.A.; Yan, W.; Jia, M.; Fjellstrom, R.; McClung, A.M. Genetic structure associated with diversity and geographic distribution in the USDA rice world collection. Nat. Sci. 2010, 2, 247-291. [CrossRef]

42. Ali, J.; Xu, J.; Ismail, A.M.; Fu, B.Y.; Vijaykumar, C.H.M.; Gao, Y.M.; Domingo, J.; Maghirang, R.; Yu, S.B.; Gregorio, G.; et al. Hidden diversity for abiotic and biotic stress tolerances in the primary gene pool of rice revealed by a large backcross breeding program. Field Crops Res. 2006, 97, 66-76. [CrossRef]

43. MacDonald, G.K.; Bennett, E.M.; Potter, P.A.; Ramankutty, N. Agronomic phosphorus imbalances across the world's croplands. Proc. Natl. Acad. Sci. USA 2007, 108, 3086-3091. [CrossRef] [PubMed]

44. Cordell, D.; Drangert, J.O.; White, S. The story of phosphorus global food security and food for thought. Glob. Environ. Chang. 2009, 19, 92-305. [CrossRef]

45. Rose, T.J.; Wissuwa, M. Rethinking internal phosphorus utilization efficiency: A new approach is needed to improve PUE in grain crops. Adv. Agron. 2012, 116, 185-217.

46. Krishnamurthy, P.; Sreedevi, B.; Ram, T.; Padmavathi, G.; Kumar, R.M.; Rao, P.R; Rani, N.S.; Latha, P.C.; Singh, S.P. Evaluation of rice genotypes for phosphorus use efficiency under soil mineral stress conditions. Oryza 2010, 47, 29-33.

47. Fageria, N.K.; Morais, O.P.; Baligar, V.C.; Wrigh, R.J. Response of rice cultivars to phosphorus supply on an Oxisol. Fertilizer Res. 1988, 16, 195-206. [CrossRef]

48. Saito, K.; Vandamme, E.; Segda, Z.; Fofana, M.; Ahouanton, K. A screening protocol for vegetative-stage tolerance to phosphorus deficiency in upland rice. Crop Sci. 2015, 55, 1223-1229. [CrossRef]

49. Li, Z.K.; Fu, B.Y.; Gao, Y.M.; Xu, J.L.; Ali, J.; Lafitte, H.R.; Jiang, Y.Z.; Rey, J.D.; Vijayakumar, C.H.; Maghirang, R.; et al. Genome-wide ILs and Their Use in Genetic and Molecular Dissection of Complex Phenotypes in Rice (Oryza sativa L.). Plant Mol. Biol. 2005, 59, 33-52. [CrossRef] [PubMed]

50. Panigrahy, M.; Rao, D.N.; Sarla, N. Molecular mechanisms in response to phosphate starvation in rice. Biotechnol. Adv. 2009, 27, 389-397. [CrossRef] [PubMed]

51. Wissuwa, M.; Kretzschmar, T.; Rose, T.J. From promise to application: Root traits for enhanced nutrient capture in rice breeding. J. Exp. Bot. 2016, 67, 3605-3615. [CrossRef] [PubMed]

52. Vejchasarn, P.; Lynch, J.P.; Brown, K.M. Genetic Variability in Phosphorus Responses of Rice Root Phenotypes. Rice 2016, 9, 29. [CrossRef] [PubMed]

53. Aluwihare, Y.C.; Ishan, M.; Chamikara, M.D.M.; Weebadde, C.K.; Sirisena, D.N.; Samarasinghe, W.L.G.; Sooriyapathirana, S.D.S.S. Characterization and Selection of Phosphorus Deficiency Tolerant Rice Genotypes in Sri Lanka. Rice Sci. 2016, 23, 184-195. [CrossRef]

54. Mahender, A.; Anandan, A.; Pradhan, S.K.; Singh, O.N. Traits-related QTLs and genes and their potential applications in rice improvement under low phosphorus condition. Arch. Agron. Soil Sci. 2017, 64, 449-464. [CrossRef]

55. Yugandhar, P.; Veronica, N.; Panigrahy, M.; Nageswara Rao, D.; Subrahmanyam, D.; Voleti, S.R.; Mangrauthia, S.K.; Sharma, R.P.; Sarla, N. Comparing Hydroponics, Sand, and Soil Medium to Evaluate Contrasting Rice Nagina 22 Mutants for Tolerance to Phosphorus Deficiency. Crop Sci. 2017, 57, 1-9. [CrossRef]

56. Chithrameenal, K.; Vellaikumar, S.; Ramalingam, J. Identification of rice (Oryza sativa L.) genotypes with high phosphorus use efficiency (PUE) under field and hydroponic conditions. Indian Res. J. Genet. Biotechnol. 2017, 9, 23-37.

57. Chin, J.H.; Gamuyao, R.; Dalid, C.; Bustamam, M.; Prasetiyono, J.; Moeljopawiro, S.; Wissuwa, M.; Heuer, S. Developing rice with high yield under phosphorus deficiency: Pup1 sequence to application. Plant Physiol. 2011, 156, 1202-1216. [CrossRef] [PubMed] 
58. Sirisena, D.N.; Wanninayake, W.M.N. Identification of promising rice varieties for low fertile soils in the low country intermediate zone in Sri Lanka. Ann. Sri Lanka Dep. Agric. 2014, 14, 95-105.

59. Cancellier, E.L.; Brandao, D.R.; Silva, J.; Santos, M.M.; Fidelis, R.R. Phosphorus use efficiency of upland rice cultivars on Cerrado soil. Ambience 2012, 8, 307-318.

60. Fageria, N.K.; Knupp, A.M.; Moraes, M.F. Phosphorus Nutrition of Lowland Rice in Tropical Lowland Soil. Commun. Soil Sci. Plant Anal. 2013, 44, 2932-2940. [CrossRef]

61. Panigrahy, M.; Nageswara Rao, D.; Yugandhar, P.; Sravan Raju, N.; Krishnamurthy, P.; Voleti, S.R.; Ashok Reddy, G.; Mohapatra, T.; Robin, A.; Singh, A.K.; et al. Hydroponic experiment for identification of tolerance traits developed by rice Nagina 22 mutants to low-phosphorus in field condition. Arch. Agron. Soil Sci. 2014, 60, 565-576. [CrossRef]

62. Wu, P.; Ma, L.; Hou, X. Phosphate starvation triggers distinct alterations of genome expression in Arabidopsis roots and leaves. Plant Physiol. 2003, 132, 1260-1271. [CrossRef] [PubMed]

63. Li, J.; Xie, Y.; Dai, A.; Liu, L.; Li, Z. Root and shoot traits responses to phosphorus deficiency and QTL analysis at seedling stage using ILs of rice. J. Genet. Genom. 2009, 36, 173-183. [CrossRef]

64. Li, L.; Qiu, X.; Li, X.; Wang, S.; Zhang, Q.; Lian, X.M. Transcriptomic analysis of rice responses to low phosphorus stress. Chin. Sci. Bull. 2010, 55, 251-258. [CrossRef]

65. Wissuwa, M.; Yano, M.; Ae, N. Mapping of QTLs for phosphorus-deficiency tolerance in rice (Oryza sativa L.). Theor. Appl. Genet. 1998, 97, 777-783. [CrossRef]

66. Wissuwa, M.; Ae, N. Further characterization of two QTLs that increase phosphorus uptake of rice (Oryza sativa L.) under phosphorus deficiency. Plant Soil. 2001, 237, 275-286. [CrossRef]

67. Guo, Y.; Lin, W.; Shi, Q.; Liang, Y.; Chen, F.; He, H.; Liang, K. Screening methodology for rice (Oryza sativa) genotypes with high phosphorus use efficiency at their seedling stage. J. Appl. Ecol. 2002, 13, 1587-1591.

68. Yuan, H.; Liu, D. Signaling components involved in plant responses to phosphate starvation. J. Integr. Plant Biol. 2008, 50, 849-859. [CrossRef] [PubMed]

69. Chin, J.H.; Lu, X.; Haefele, S.M.; Gamuyao, R.; Ismail, A.; Wissuwa, M.; Heuer, S. Development and application of gene-based markers for the major rice QTL Phosphate uptake 1. Theor. Appl. Genet. 2010, 120, 1073-1086. [CrossRef] [PubMed]

70. Ramaekers, L.; Remans, R.; Rao, I.M.; Blair, M.W.; Vanderleyden, J. Strategies for improving phosphorus acquisition efficiency of crop plants. Field Crops Res. 2010, 117, 169-176. [CrossRef]

71. Wissuwa, M.; Mazzola, M.; Picard, C. Novel approaches in plant breeding for rhizosphere-related traits. Plant Soil 2009, 321, 409-430. [CrossRef]

72. Chen, L.; Lin, L.; Cai, G.; Sun, Y.; Huang, T.; Wang, K.; Deng, J. Identification of Nitrogen, Phosphorus, and Potassium Deficiencies in Rice Based on Static Scanning Technology and Hierarchical Identification Method. PLoS ONE 2014, 9, e113200. [CrossRef] [PubMed]

73. Place, G.A.; Sims, J.L.; Hall, U.L. Effects of nitrogen and phosphorous on the growth yield and cooking characteristics of rice. Agron. J. 1970, 62, 239-241. [CrossRef]

74. Nguyen, H.T.T.; Pham, C.V.; Bertin, P. The effect of nitrogen concentration on nitrogen use efficiency and related parameters in cultivated rices (Oryza sativa L. subsp. indica and japonica and O. glaberrima Steud.) in hydroponics. Euphytica 2014, 198, 137-151. [CrossRef]

75. Vitousek, P.M.; Naylor, R.; Crews, T.; David, M.B.; Drinkwater, L.E.; Holland, E.; Johnes, P.J.; Katzenberger, J.; Martinelli, L.A.; Matson, P.A.; et al. Agriculture. Nutrient imbalances in agricultural development. Science 2009, 324, 1519-1520. [CrossRef] [PubMed]

76. Bouwman, A.F.; Boumans, L.J.M.; Batjes, N.H. Emissions of $\mathrm{N}_{2} \mathrm{O}$ and $\mathrm{NO}$ from fertilised fields: Summary of available measurement data. Glob. Biogeochem. Cycles 2002, 16, 6-1-6-13. [CrossRef]

77. Samborski, S.; Kozak, M.; Azevedo, R.A. Does nitrogen uptake affect nitrogen uptake efficiency or vice versa? Acta Physiol. Plant. 2008, 30, 419-420. [CrossRef]

78. Li, Y.; Yang, X.; Ren, B.; Shen, Q.; Guo, S. Why nitrogen use efficiency decreases under high nitrogen supply in rice (Oryza sativa L.) seedlings. J. Plant Growth Regul. 2012, 31, 47-52. [CrossRef]

79. Singh, H.; Verma, A.; Ansari, M.A.; Shukla, A. Physiological response of rice (Oryza sativa L.) genotypes to elevated nitrogen applied under field conditions. Plant Signal. Behav. 2015, 9, e29015. [CrossRef] [PubMed]

80. Chaturvedi, I. Effect of Nitrogen Fertilizers on Growth, Yield and Quality of Hybrid Rice (Oryza sativa L.). J. Cent. Eur. Agric. 2005, 6, 611-618. 
81. Manzoor, Z.; Awan, T.H.; Zahid, M.A.; Faiz, F.A. Response of rice crop (Super Basmati) to different nitrogen levels. J. Anim. Plant Sci. 2006, 16, 1-2.

82. Swamy, K.N.; Kondamudi, R.; Kiran, T.V.; Vijayalakshmi, P.; Rao, Y.V.; Rao, P.R.; Subrahmanyam, D.; Voleti, S.R. Screening for nitrogen use efficiency with their root characteristics in rice (Oryza spp.) genotypes. Ann. Biol. Sci. 2015, 3, 8-11.

83. Haque, M.A.; Haque, M.M. Growth, Yield and Nitrogen Use Efficiency of New Rice Variety under Variable Nitrogen Rates. Am. J. Plant Sci. 2016, 7, 612-622. [CrossRef]

84. Kumagai, E.; Araki, T.; Kubota, F. Effects of nitrogen supply restriction on gas exchange and photosystem 2 function in flag leaves of a traditional low-yield cultivar and a recently improved high-yield cultivar of rice (Oryza sativa L.). Photosynthetica 2007, 45, 489-495. [CrossRef]

85. Maske, N.S.; Borkar, S.L.; Rajgire, H.J. Effects of Nitrogen Levels on Growth, Yield and Grain Quality of Rice. J. Soil Crop 1997, 7, 83-86.

86. Peng, S.; Cassman, K.G.; Virmani, S.S.; Sheehy, J.; Khush, G.S. Yield potential trends of tropical rice since the release of IR8 and the challenge of increasing rice yield potential. Crop Sci. 1999, 39, 1552-1559. [CrossRef]

87. Lawlor, D.W. Carbon and nitrogen assimilation in relation to yield: Mechanisms are the key to understanding production systems. J. Exp. Bot. 2002, 53, 773-787. [CrossRef] [PubMed]

88. Yang, J.; Peng, S.; Zhang, Z.; Wang, Z.; Visperas, R.M.; Zhu, Q. Grain and dry matter yields and portioning of assimilates in Japonica/Indica hybrid rice. Crop Sci. 2002, 42, 766-772. [CrossRef]

89. Ahmed, M.; Islam, M.M.; Paul, S.K.; Khulna, B. Effect of Nitrogen on Yield and Other Plant Characters of Local, T. Aman Rice Var. Jatai. Res. J. Agric. Biol. Sci. 2005, 1, 158-161.

90. Hamaoka, N.; Uchida, Y.; Tomita, M.; Kumagai, E.; Araki, T.; Ueno, O. Genetic variations in dry matter production, nitrogen uptake, and nitrogen use efficiency in the AA genome Oryza species grown under different nitrogen conditions. Plant Prod. Sci. 2013, 16, 107-116. [CrossRef]

91. Yogendra, N.D.; Kumara, B.H.; Chandrashekar, N.; Prakash, N.B.; Anantha, M.S.; Shashidhar, H.E. Real-time nitrogen management in aerobic rice by adopting leaf color chart (LCC) as influenced by silicon. J. Plant Nutr. 2017, 40, 1277-1286. [CrossRef]

92. Mandal, N.N.; Chaudhry, P.P.; Sinha, D. Nitrogen, phosphorus and potash uptake of wheat (var. Sonalika). Environ. Ecol. 1992, 10, 297.

93. Wang, Y.; Wu, W.H. Genetic approaches for improvement of the crop potassium acquisition and utilization efficiency. Curr. Opin. Plant Biol. 2015, 25, 46-52. [CrossRef] [PubMed]

94. FAO. Current World Fertilizer Trends and Outlook to 2016; Food and Agriculture Organization of the United Nations: Rome, Italy, 2012.

95. Dobermann, A.; Cassman, K.G.; Mamaril, C.P.; Sheehy, J.E. Management of phosphorus, potassium and sulfur in intensive irrigated lowland rice. Field Crops Res. 1998, 56, 113-138. [CrossRef]

96. Xiaoe, Y.; Romheld, V.; Marschner, H.; Baligar, V.C.; Martens, D.C. Shoot photosynthesis and root growth of hybrid and conventional rice cultivars as affected by $\mathrm{N}$ and $\mathrm{K}$ levels in the root zone. Pedosphere 1997, 7, 35-42.

97. Epstein, E.; Bloom, A.J. Mineral Nutrition of Plants: Principles and Perspectives, 2nd ed.; Sinauer Associates: Sunderland, MA, USA, 2005.

98. Fageria, N.K.; Dos Santos, A.B.; Moreira, A.; Moraes, M.F. Potassium soil test calibration for lowland rice on an inceptisol. Commun. Soil Sci. Plant Anal. 2010, 41, 2595-2601. [CrossRef]

99. Grzebisz, W.; Gransee, A.; Szczepaniak, W. The effects of potassium fertilization on water-use efficiency in crop plants. J. Pant Nutr. Soil Sci. 2013, 176, 355-374. [CrossRef]

100. Mehdi, S.M.; Sarfraz, M.; Hafeez, M. Response of rice advanced line PB-95 to potassium in saline sodic soil. Pak. J. Biol. Sci. 2007, 10, 2938-2939.

101. Fageria, N.K.; Dos Santos, A.B.; De Moraes, M.F. Yield, Potassium Uptake, and Use Efficiency in Upland Rice Genotypes. Commun. Soil Sci. Plant Anal. 2010, 41, 2676-2684. [CrossRef]

102. Arif, M.; Arshad, M.; Asghar, H.N.; Basara, S.M.A. Response of rice (Oryza sativa) genotypes varying in K use efficiency to various levels of potassium. Int. J. Agric. Biol. 2010, 12, 926-930.

103. Kalita, U.; Ojha, N.J.; Talukdar, M.C. Effect of levels and time of potassium application on yield and yield attributes of upland rice. J. Potassium Res. 1993, 11, 203-206.

104. Dunn, D.; Stevens, G. Rice potassium nutrition research progress (Missouri). Better Crops 2005, 89, $15-17$. 
105. Awan, T.H.; Manzoor, Z.; Safdar, M.E.; Ahmad, M. Yield response of rice to dynamic use of potassium in traditional rice growing area of Punjab. Pak. J. Agric. Sci. 2007, 44, 130-135.

106. Bahmaniar, M.A.; Ranjbar, G.A. Effects of nitrogen and potassium fertilizers on rice (Oryza sativa L.) genotypes processing characteristics. Pak. J. Biol. Sci. 2007, 10, 1829-1834. [PubMed]

107. Sarkar, R.K.; Malik, G.C. Effect of foliar spray of $\mathrm{KNO}_{3}$ and $\mathrm{Ca}\left(\mathrm{NO}_{3}\right)^{2}$ on grass pea (Lathyrus sativus L.) grown in rice fallows. Lathyrus Lathyrism Newslett. 2001, 2, 47-48.

108. Islam, A.; Saha, P.K.; Biswas, J.C.; Saleque, M.A. Potassium Fertilization in Intensive Wetland Rice System: Yield, Potassium Use Efficiency and Soil Potassium Status. Int. J. Agric. Pap. 2016, 1, 7-21.

109. De, D.S.K.; Broadbent, F.E. Development changes related to nitrogen-use efficiency in rice. Field Crops Res. 1993, 34, 47-56.

110. William, R.R.; Johnson, G.V. Improving nitrogen use efficiency for cereal production. Agron. J. 1999, 91,357-363.

111. Gregard, A.; Gelanger, G.; Michaud, R. Nitrogen use efficiency and morphological characteristics of timothy populations selected for low and high forage nitrogen concentrations. Crop Sci. 2000, 40, 422-429. [CrossRef]

112. Anil, K.; Nidhi, G.; Atul, K.G.; Vikram, S.G. Identification of Biomarker for Determining Genotypic Potential of Nitrogen-Use-Efficiency and Optimization of the Nitrogen Inputs in Crop Plants. J. Crop Sci. Biotechnol. 2009, 12, 183-194.

113. Pingali, P.L. Green revolution: Impacts, limits, and the path ahead. Proc. Natl. Acad. Sci. USA 2012, 109, 12302-12308. [CrossRef] [PubMed]

114. Beatty, P.H.; Shrawat, A.K.; Carroll, R.T.; Zhu, T.; Good, A.G. Transcriptome analysis of nitrogen-efficient rice over-expressing alanine aminotransferase. Plant Biotechnol. J. 2009, 7, 562-576. [CrossRef] [PubMed]

115. Kant, S.; Bi, Y.; Rothstein, S.J. Understanding plant response to nitrogen limitation for the improvement of crop nitrogen use efficiency. J. Exp. Bot. 2011, 62, 1499-1509. [CrossRef] [PubMed]

116. Kabir, G. Genetic approaches of increasing nutrient use efficiency especially nitrogen in cereal crops-A review. J. Bio-Sci. 2014, 22, 111-125. [CrossRef]

117. Rose, T.J.; Kretzschmar, T.; Waters, D.L.E.; Balindong, J.L.; Wissuwa, M. Prospects for Genetic Improvement in Internal Nitrogen Use Efficiency in Rice. Agronomy 2017, 7, 70. [CrossRef]

118. Zhou, Y.; Tao, Y.; Tang, D.; Wang, J.; Zhong, J.; Wang, Y.; Yuan, Q.; Yu, X.; Zhang, Y. Identification of QTL Associated with Nitrogen Uptake and Nitrogen Use Efficiency Using High Throughput Genotyped CSSLs in Rice (Oryza sativa L.). Front. Plant Sci. 2017, 8, 1166. [CrossRef] [PubMed]

119. Sinha, S.K.; Sevanthi, V.A.M.; Chaudhary, S.; Tyagi, P.; Venkadesan, S.; Rani, M.; Mandal, P.K. Transcriptome Analysis of Two Rice Varieties Contrasting for Nitrogen Use Efficiency under Chronic N Starvation Reveals Differences in Chloroplast and Starch Metabolism-Related Genes. Genes (Basel) 2018, 11, E206. [CrossRef] [PubMed]

120. Duan, Y.H.; Zhang, Y.L.; Ye, L.T.; Fan, X.R.; Xu, G.H.; Shen, Q.R. Responses of Rice Cultivars with Different Nitrogen Use Efficiency to Partial Nitrate Nutrition. Ann. Bot. 2007, 99, 1153-1160. [CrossRef] [PubMed]

121. Fan, X.; Xie, D.; Chen, J.; Lu, H.; Xu, Y.; Ma, C.; Xu, G. Over-expression of OsPTR6 in rice increased plant growth at different nitrogen supplies but decreased nitrogen use efficiency at high ammonium supply. Plant Sci. 2014, 227, 1-11. [CrossRef] [PubMed]

122. Ashikari, M.; Sakakibara, H.; Lin, S.; Yamamoto, T.; Takashi, T.; Nishimura, A.; Angeles, E.R.; Qian, Q.; Kitano, H.; Matsuoka, M. Cytokinin oxidase regulates rice grain production. Science 2005, 309, 741-745. [CrossRef] [PubMed]

123. Huang, X.; Qian, Q.; Liu, Z.; Sun, H.; He, S.; Luo, D.; Xia, G.; Chu, C.; Li, J.; Fu, X. Natural variation at the DEP1 locus enhances grain yield in rice. Nat. Genet. 2009, 41, 494-497. [CrossRef] [PubMed]

124. Miura, K.; Ikeda, M.; Matsubara, A.; Song, X.J.; Ito, M.; Asano, K.; Matsuoka, M.; Kitano, H.; Ashikari, M. OsSPL14 promotes panicle branching and higher grain productivity in rice. Nat. Genet. 2010, 42, 545-549. [CrossRef] [PubMed]

125. Jiao, Y.; Wang, Y.; Xue, D.; Wang, J.; Yan, M.; Liu, G.; Dong, G.; Zeng, D.; Lu, Z.; Zhu, X.; Qian, Q.; Li, J. Regulation of OsSPL14 by OsmiR156 defines ideal plant architecture in rice. Nat. Genet. 2010, 42, 541-544. [CrossRef] [PubMed]

126. Song, X.J.; Huang, W.; Shi, M.; Zhu, M.Z.; Lin, H.X. A QTL for rice grain width and weight encodes a previously unknown RING-type E3 ubiquitin ligase. Nat. Genet. 2007, 39, 623-630. [CrossRef] [PubMed] 
127. Shomura, A.; Izawa, T.; Ebana, K.; Ebitani, T.; Kanegae, H.; Konishi, S.; Yano, M. Deletion in a gene associated with grain size increased yields during rice domestication. Nat. Genet. 2008, 40, 1023-1028. [CrossRef] [PubMed]

128. Weng, J.; Gu, S.; Wan, X.; Gao, H.; Guo, T.; Su, N.; Lei, C.; Zhang, X.; Cheng, Z.; Guo, X.; et al. Isolation and initial characterization of GW5, a major QTL associated with rice grain width and weight. Cell Res. 2008, 18, 1199-1209. [CrossRef] [PubMed]

129. Wang, E.; Wang, J.; Zhu, X.; Hao, W.; Wang, L.; Li, Q.; Zhang, L.; He, W.; Lu, B.; Lin, H.; et al. Control of rice grain-filling and yield by a gene with a potential signature of domestication. Nat. Genet. 2008, 40, 1370-1374. [CrossRef] [PubMed]

130. Yano, M.; Katayose, Y.; Ashikari, M.; Yamanouchi, U.; Monna, L.; Fuse, T.; Baba, T.; Yamamoto, K.; Umehara, Y.; Nagamura, Y.; et al. Hd1, a major photoperiod sensitivity quantitative trait locus in rice, is closely related to the Arabidopsis flowering time gene CONSTANS. Plant Cell 2000, 12, 2473-2483. [CrossRef] [PubMed]

131. Takahashi, Y.; Shomura, A.; Sasaki, T.; Yano, M. Hd6, a rice quantitative trait locus involved in photoperiod sensitivity, encodes the subunit of protein kinase CK2. Proc. Natl. Acad. Sci. USA 2001, 98, 7922-7927. [CrossRef] [PubMed]

132. Kojima, S.; Takahashi, Y.; Kobayashi, Y.; Monna, L.; Sasaki, T.; Araki, T.; Yano, M. Hd3a, a rice ortholog of the Arabidopsis FT gene, promotes transition to flowering downstream of Hd1 under shortday conditions. Plant Cell Physiol. 2002, 43, 1096-1105. [CrossRef] [PubMed]

133. Izawa, T.; Oikawa, T.; Sugiyama, N.; Tanisaka, T.; Yano, M.; Shimamoto, K. Phytochrome mediates the external light signal to repress FT orthologs in photoperiodic flowering of rice. Genes Dev. 2002, 16, 2006-2020. [CrossRef] [PubMed]

134. Tamaki, S.; Matsuo, S.; Wong, H.L.; Yokoi, S.; Shimamoto, K. Hd3a protein is a mobile flowering signal in rice. Science 2007, 316, 1033-1036. [CrossRef] [PubMed]

135. Doi, K.; Izawa, T.; Fuse, T.; Yamanouchi, U.; Kubo, T.; Shimatani, Z.; Yano, M.; Yoshimura, A. Ehd1, a B-type response regulator in rice, confers short-day promotion of flowering and controls FT-like gene expression independently of Hd1. Genes Dev. 2004, 18, 926-936. [CrossRef] [PubMed]

136. Xue, W.; Xing, Y.; Weng, X.; Zhao, Y.; Tang, W.; Wang, L.; Zhou, H.; Yu, S.; Xu, C.; Li, X.; Zhang, Q. Natural variation in Ghd7 is an important regulator of heading date and yield potential in rice. Nat. Genet. 2008, 40, 761-767. [CrossRef] [PubMed]

137. Wei, X.; Xu, J.; Guo, H.; Jiang, L.; Chen, S.; Yu, C.; Zhou, Z.; Hu, P.; Zhai, H.; Wan, J. DTH8 suppresses flowering in rice, influencing plant height and yield potential simultaneously. Plant Physiol. 2010, 153, 1747-1758. [CrossRef] [PubMed]

138. Sasaki, A.; Ashikari, M.; Ueguchi-Tanaka, M.; Itoh, H.; Nishimura, A.; Swapan, D.; Ishiyama, K.; Saito, T.; Kobayashi, M.; Khush, G.S.; et al. Green revolution: A mutant gibberellin-synthesis gene in rice. Nature 2002, 416, 701-702. [CrossRef] [PubMed]

139. Ookawa, T.; Hobo, T.; Yano, M.; Murata, K.; Ando, T.; Miura, H.; Asano, K.; Ochiai, Y.; Ikeda, M.; Nishitani, R.; et al. New approach for rice improvement using a pleiotropic QTL gene for lodging resistance and yield. Nat. Commun. 2010, 1, 132. [CrossRef] [PubMed]

140. Fukuoka, S.; Saka, N.; Koga, H.; Ono, K.; Shimizu, T.; Ebana, K.; Hayashi, N.; Takahashi, A.; Hirochika, H.; Okuno, K.; Yano, M. Loss of function of a proline-containing protein confers durable disease resistance in rice. Science 2009, 325, 998-1001. [CrossRef] [PubMed]

141. Hayashi, N.; Inoue, H.; Kato, T.; Funao, T.; Shirota, M.; Shimizu, T.; Kanamori, H.; Yamane, H.; Hayano-Saito, Y.; Matsumoto, T. Durable panicle blast-resistance gene Pb1 encodes an atypical CC-NBS-LRR protein and was generated by acquiring a promoter through local genome duplication. Plant J. 2010, 64, 498-510. [CrossRef] [PubMed]

142. Ren, Z.H.; Gao, J.P.; Li, L.G.; Cai, X.L.; Huang, W.; Chao, D.Y.; Zhu, M.Z.; Wang, Z.Y.; Luan, S.; Lin, H.X. A rice quantitative trait locus for salt tolerance encodes a sodium transporter. Nat. Genet. 2005, 37, 1141-1146. [CrossRef] [PubMed]

143. Fujino, K.; Sekiguchi, H.; Matsuda, Y.; Sugimoto, K.; Ono, K.; Yano, M. Molecular identification of a major quantitative trait locus, qLTG3-1, controlling low-temperature germinability in rice. Proc. Natl. Acad. Sci. USA 2008, 105, 12623-12628. [CrossRef] [PubMed] 
144. Xu, K.; Xu, X.; Fukao, T.; Canlas, P.; Maghirang-Rodriguez, R.; Heuer, S.; Ismail, A.M.; Bailey-Serres, J.; Ronald, P.C.; Mackill, D.J. Sub1A is an ethylene-response-factor-like gene that confers submergence tolerance to rice. Nature 2006, 442, 705-708. [CrossRef] [PubMed]

145. Hattori, U.Y.; Nagai, K.; Furukawa, S.; Song, X.J.; Kawano, R.; Sakakibara, H.; Wu, J.; Matsumoto, T.; Yoshimura, A.; Kitano, H.; Matsuoka, M. The ethylene response factors SNOKEL1 and SNOKEL2 allow rice to adapt to deep water. Nature 2009, 460, 1026-1030. [CrossRef] [PubMed]

146. Ueno, D.; Koyama, E.; Kono, I.; Ando, T.; Yano, M.; Ma, J.F. Identification of a novel major quantitative trait locus controlling distribution of Cd between roots and shoots in rice. Plant Cell Physiol. 2009, 50, 2223-2233. [CrossRef] [PubMed]

147. Li, C.; Zhou, A.; Sang, T. Rice domestication by reducing shattering. Science 2006, 311, 1936-1939. [CrossRef] [PubMed]

148. Konishi, S.; Izawa, T.; Lin, S.Y.; Ebana, K.; Fukuta, Y.; Sasaki, T.; Yano, M. An SNP caused loss of seed shattering during rice domestication. Science 2006, 312, 1392-1396. [CrossRef] [PubMed]

149. Tan, L.; Li, X.; Liu, F.; Sun, X.; Li, C.; Zhu, Z.; Fu, Y.; Cai, H.; Wang, X.; Xie, D.; Sun, C. Control of a key transition from prostrate to erect growth in rice domestication. Nat. Genet. 2008, 40, 1360-1364. [CrossRef] [PubMed]

150. Jin, J.; Huang, W.; Gao, J.P.; Yang, J.; Shi, M.; Zhu, M.Z.; Luo, D.; Lin, H.X. Genetic control of rice plant architecture under domestication. Nat. Genet. 2008, 40, 1365-1369. [CrossRef] [PubMed]

151. Romero, L.E.; Lozano, I.; Garavito, A.; Carabali, S.J.; Triana, M.; Villareal, N.; Reyes, L.; Duque, M.C.; Martinez, C.P. Major QTLs Control Resistance to Rice Hoja Blanca Virus and Its Vector Tagosodes orizicolus. G3 (Bethesda) 2014, 4, 133-142. [CrossRef] [PubMed]

152. Uga, Y.; Yamamoto, E.; Kanno, N.; Kawai, S.; Mizubayashi, T.; Fukuoka, S. A major QTL controlling deep rooting on rice chromosome 4. Sci. Rep. 2013, 3, 3040. [CrossRef] [PubMed]

153. Ni, J.J.; Wu, P.; Senadhira, D.; Huang, N. Mapping QTLs for phosphorus deficiency tolerance in rice (Oryza sativa L.). Theor. Appl. Genet. 1998, 97, 1361-1369. [CrossRef]

154. Wissuwa, M.; Wegner, J.; Ae, N.; Yano, M. Substitution mapping of Pup1: A major QTL increasing phosphorus uptake of rice from a phosphorus-deficient soil. Theor. Appl. Genet. 2002, 105, 890-897. [PubMed]

155. Shimizu, A.; Yanagihara, S.; Kawasaki, S.; Ikehashi, H. Phosphorus deficiency-induced root elongation and its QTL in rice (Oryza sativa L.). Theor. Appl. Genet. 2004, 109, 1361-1368. [CrossRef] [PubMed]

156. Lang, N.T.; Buu, B.C. Mapping QTLs for phosphorus deficiency tolerance in rice (Oryza sativa L.). Omonrice 2006, 14, 1-9.

157. Shimizu, A.; Kato, K.; Komatsu, A.; Motomura, K.; Ikehashi, H. Genetic analysis of root elongation induced by phosphorus deficiency in rice (Oryza sativa L.): Fine QTL mapping and multivariate analysis of related traits. Theor. Appl. Genet. 2008, 117, 987-996. [CrossRef] [PubMed]

158. Chao, X.; Jie, R.; Xiu-qin, Z.; Zai-song, D.; Jing, Z.; Chao, W.; Jun-wei, Z.; Joseph, C.A.; Qiang, Z.; et al. Genetic Dissection of Low Phosphorus Tolerance Related Traits Using Selected Introgression Lines in Rice. Rice Sci. 2015, 22, 264-274. [CrossRef]

159. Wang, K.; Cui, K.; Liu, G.; Xie, W.; Yu, H.; Pan, J.; Huang, J.; Nie, L.; Shah, F. Identification of quantitative trait loci for phosphorus use efficiency traits in rice using a high density SNP map. BMC Genet. 2014, 15, 155. [CrossRef] [PubMed]

160. Feng, M.; Xianwu, Z.; Guohua, M.; He, P.; Zhu, L.; Zhang, F. Identification of quantitative trait loci affecting tolerance to low phosphorus in rice (Oryza sativa L.). Chin. Sci. Bull. 2000, 45, 519-525.

161. Fang, P.; Wu, P. QTL x N-level interaction for plant height in rice (Oriza sativa L.). Plant Soil 2001, 236, $237-242$. [CrossRef]

162. Ishimaru, K.; Kobayashi, N.; Ono, K.; Yano, M.; Ohsugi, R. Are contents of Rubisco, soluble protein and nitrogen in flag leaves of rice controlled by the same genetics? J. Exp. Bot. 2001, 52, 1827-1833. [CrossRef] [PubMed]

163. Ogawa, S.; Valencia, M.O.; Lorieux, M.; Arbelaez, J.D.; McCouch, M.; Ishitani, M.; Selvaraj, M.G. Identification of QTLs associated with agronomic performance under nitrogen-deficient conditions using chromosome segment substitution lines of a wild rice relative, Oryza rufipogon. Acta Physiol. Plant. 2016, 38, 103. [CrossRef]

164. Obara, M.; Kajiura, M.; Fukuta, Y.; Yano, M.; Hayashi, M.; Yamaya, T.; Sato, T. Mapping of QTLs associated with cytosolic glutamine synthetase and NADH- glutamate synthase in rice (Oryza sativa L.). J. Exp. Bot. 2001, 52, 1209-1217. [PubMed] 
165. Senthilvel, S.; Govindaraj, P.; Arumugachamy, S.; Latha, R.; Malarvizhi, P.; Gopalan, A.; Maheswaran, M. Mapping genetic loci associated with nitrogen use efficiency in rice (Oryza sativa L.). In Proceedings of the 4th International Crop Science Congress, Brisbane, Australia, 26 September-1 October 2004.

166. Tong, H.H.; Mei, H.W.; Yu, X.Q.; Xu, X.Y.; Li, M.S.; Zhang, S.Q.; Luo, L.J. Identification of Related QTLs at Late Developmental Stage in Rice (Oryza sativa L.) Under Two Nitrogen Levels. Acta Genet. Sin. 2006, 33, 458-467. [CrossRef]

167. Wang, Y.; Sun, Y.J.; Chen, D.Y.; Yu, S.B. Analysis of Quantitative Trait Loci in Response to Nitrogen and Phosphorus Deficiency in Rice Using Chromosomal Segment Substitution Lines. Acta Agron. Sin. 2009, 35, 580-587. [CrossRef]

168. Laza, M.R.; Kondo, M.; Ideta, O.; Barleen, E.; Imbe, T. Identification of quantitative trait loci for d13C and productivity in irrigated lowland rice. Crop Sci. 2006, 46, 763-773. [CrossRef]

169. MacMillan, K.; Emrich, K.; Piepho, H.P.; Mullins, C.E.; Price, A.H. Assessing the importance of genotype $\times$ environment interaction for root traits in rice using a mapping population II: Conventional QTL analysis. Theor. Appl. Genet. 2006, 113, 953-964. [CrossRef] [PubMed]

170. Cho, Y.I.; Jiang, W.Z.; Chin, J.H.; Piao, Z.; Cho, Y.G.; McCouch, S.; Koh, H.J. Identification of QTLs associated with physiological nitrogen use efficiency in rice. Mol. Cell 2007, 23, 72-79.

171. Senthilvel, S.; Vinod, K.K.; Malarvizhi, P.; Maheswaran, M. QTL and QTL $\times$ environment effects on agronomic and nitrogen acquisition traits in rice. J. Integr. Plant Biol. 2008, 50, 1108-1117. [CrossRef] [PubMed]

172. Piao, Z.; Li, M.; Li, P.; Zhang, C.; Wang, H.; Luo, Z.; Lee, J.; Yang, R. Bayesian dissection for genetic architecture of traits associated with nitrogen utilization efficiency in rice. Afr. J. Biotechnol. 2009, 8, 6834-6839.

173. Srividya, A.; Vemireddy, L.R.; Hariprasad, A.S.; Jayaprada, M.; Sakile, S.; Puram, V.R.R.; Anuradha, G.; Siddiq, E.A. Identification and mapping of landrace derived QTL associated with yield and its components in rice under different nitrogen levels and environments. Int. J. Plant Breed. Genet. 2010, 4, 210-227. [CrossRef]

174. Tong, H.H.; Chen, L.; Li, W.P.; Mei, H.; Xing, Y.; Yu, X.; Xu, X.; Zhang, S.; Luo, L. Identification and characterization of quantitative trait loci for grain yield and its components under different nitrogen fertilization levels in rice (Oryza sativa L.). Mol. Breed. 2011, 28, 495-509. [CrossRef]

175. Yue, F.; Rong-rong, Z.; Ze-chuan, L.; Li-yong, C.; Xing-hua, W.; Shi-hua, C. Quantitative trait locus analysis for rice yield traits under two nitrogen levels. Rice Sci. 2015, 22, 108-115. [CrossRef]

176. Wei, D.; Cui, K.; Ye, G.; Pan, J.; Xiang, J.; Huang, J.; Nie, L. QTL mapping for nitrogen-use efficiency and nitrogen-deficiency tolerance traits in rice. Plant Soil 2012, 359, 281-295. [CrossRef]

177. Wu, P.; Ni, J.J.; Luo, A.C. QTLs underlying Rice Tolerance to Low-Potassium Stress in Rice Seedlings. Crop Sci. 1998, 38, 1458-1462. [CrossRef]

178. Senaratne, R.; Ratnasinghe, D.S. Nitrogen fixation and beneficial effects of some grain legumes and green-manure crops on rice. Biol. Fer. Soils 1995, 19, 49-54. [CrossRef]

179. Lin, X.Q.; Zhou, W.J.; Zhu, D.F.; Zhang, Y. Effect of water management on photosynthetic rate and water use efficiency of leaves in paddy rice. Chin. J. Rice Sci. 2004, 18, 333-338, (in Chinese with English abstract).

180. Peng, S.; Cassman, K.G. Upper thresholds of nitrogen uptake rates and associated nitrogen fertilizer efficiencies in irrigated rice. Agron. J. 1998, 90, 178-185. [CrossRef]

181. Yamaya, T.; Obara, M.; Nakajima, H.; Sasaki, S.; Hayakawa, T.; Sato, T. Genetic manipulation and quantitative trait loci mapping for nitrogen recycling in rice. J. Exp. Bot. 2002, 53, 917-925. [CrossRef] [PubMed]

182. Lian, X.; Xing, Y.; Yan, H.; Xu, C.; Li, X.; Zhang, Q. QTLs for low nitrogen tolerance at seedling stage identified using a recombinant inbred line population derived from an elite rice hybrid. Theor. Appl. Genet. 2005, 112, 85-96. [CrossRef] [PubMed]

183. De, M.; Velk, P.L.G. The role of Azolla cover in improving the nitrogen use efficiency of lowland rice. Plant Soil 2004, 263, 311-321.

184. Ladha, J.K.; Kirk, G.J.D.; Bennett, J.; Peng, S.; Reddy, C.K.; Reddy, P.M.; Singh, U. Opportunities for increased nitrogen use efficiency from improved lowland rice germplasm. Field Crops Res. 1998, 56, 41-71. [CrossRef]

185. Obara, M.; Sato, T.; Sasaki, S.; Kashiba, K.; Nagano, A.; Nakamura, I.; Ebitani, T.; Yano, M.; Yamaya, T. Identification and characterization of a QTL on chromosome 2 for cytosolic glutamine synthetase content and panicle number in rice. Theor. Appl. Genet. 2004, 110, 1-11. [CrossRef] [PubMed]

186. Shan, Y.H.; Wang, Y.; Pan, X.B. Mapping of QTLs for nitrogen use efficiency and related traits in rice (Oryza sativa L.). Agric. Sci. China 2005, 4, 721-727. 
187. Dong, G.C.; Wang, Y.L.; Zhang, Y.F.; Chen, P.; Yang, L.; Huang, J.; Zuo, B. Characteristics of yield and yield components in conventional indica rice cultivars with different nitrogen use efficiencies for grain output. Acta Agron. Sin. 2006, 32, 1511-1518.

188. Dong, G.C.; Wang, Y.; Yu, X.F. Differences of nitrogen uptake and utilization of conventional rice varieties with different growth duration. Sci. Agric. Sin. 2011, 44, 4570-4582.

189. Sanchez, P.A.; Salinas, J.G. Low-input technology for managing oxisols and ultisols in tropical America. Adv. Agron. 1981, 34, 279-406.

190. Dobermann, A.; Fairhurst, T. Rice: Nutrient Disorders \& Nutrient Management; Potash \& Phosphate Institute, Potash \& Phosphate Institute of Canada, and International Rice Research Institute: Singapore; Los Baños, Philippines, 2000.

191. Su, J.Y.; Xiao, Y.M.; Li, M.; Liu, Q.; Li, B.; Tong, Y.; Jia, J.; Li, Z. Mapping QTLs for phosphorus-deficiency tolerance at wheat seedling stage. Plant Soil 2006, 281, 25-36. [CrossRef]

192. Liu, Y.; Li, Z.C.; Mi, G.H.; Zhang, H.L.; Mu, P.; Wang, X. Screen and identification for tolerance to low-phosphorus stress of rice germplasm (Oryza sativa L.). Acta Agron. Sin. 2005, 31, 238-242. (in Chinese with English abstract)

193. Ping, M.U.; Huang, C.; Li, J.X.; Liu, L.F.; Li, Z.C. Yield Trait Variation and QTL Mapping in a DH Population of Rice Under Phosphorus Deficiency. Acta Agron. Sin. 2008, 34, 1137-1142.

194. Liu, L.J.; Chang, E.H.; Fan, M.M.; Wang, Z.Q.; Yang, J.C. Effects of Potassium and Calcium on Root Exudates and Grain Quality During Grain Filling. Acta Agron. Sin. 2011, 37, 661-669.

195. Torkashv, M.; Vahed, S. The efficiency of potassium fertilization methods on the growth of rice (Oryza sativa L.) under salinity stress. Afr. J. Biotechnol. 2011, 10, 15946-15952.

196. Ali, J.; Franje, N.J.; Revilleza, J.E.; Acero, B. Breeding for Low-Input Responsive Green Super Rice (GSR) Varieties for Rainfed Lowlands of Asia and Africa. University Library; University of the Philippines at Los Baños: Los Baños, Philippines, 2016.

197. Yorobe, J.M.; Ali, J.; Pede, V.; Rejesus, R.M.; Velarde, O.P.; Wang, W. Yield and income effects of rice varieties with tolerance of multiple abiotic stresses: The case of green super rice (GSR) and flooding in the Philippines. Agric. Econ. 2016, 47, 1-11. [CrossRef]

198. Wu, L.; Yuan, S.; Huang, L.; Sun, F.; Zhu, G.; Li, G.; Fahad, S.; Peng, S.; Wang, F. Physiological Mechanisms Underlying the High-Grain Yield and High-Nitrogen Use Efficiency of Elite Rice Varieties under a Low Rate of Nitrogen Application in China. Front. Plant Sci. 2016, 7, 1024. [CrossRef] [PubMed]

199. Wang, F.; Peng, S. Yield potential and nitrogen use efficiency of China's super rice. J. Integr. Agric. 2017, 16, 1000-1008. [CrossRef]

200. Ali, J.; Xu, J.L.; Gao, Y.; Fontanilla, M.; Li, Z.K. Breeding for yield potential and enhanced productivity across different rice ecologies through green super rice (GSR) breeding strategy. In International Dialogue on Perception and Prospects of Designer Rice; Muralidharan, K., Siddiq, E.A., Eds.; Society for the Advancement of Rice Research, Directorate of Rice Research: Hyderabad, India, 2013; pp. 60-68.

201. Mortvedt, J.J.; Murphy, L.S.; Follett, R.H. Fertilizer Technology and Application; Meister Publishing Co.: Willoughby, OH, USA, 2001.

202. Yadav, R.L. Assessing on-farm efficiency and economics of fertilizer N., P and K in rice-wheat systems of India. Field Crops Res. 2003, 18, 39-51. [CrossRef]

203. Cassman, K.G.; Gines, G.C.; Dizon, M.A.; Samson, M.I.; Alceantara, J.M. Nitrogen use efficiency in tropical lowland rice systems: Contributions from indigenous and applied nitrogen. Fields Crops Res. 1996, 47, 1-12. [CrossRef]

204. Dobermann, A.R. Nitrogen Use Efficiency-State of the Art; Agronomy-Faculty Publications: Lincoln, NE, USA, $2005 ;$ p. 316.

205. Wen-xia, X.; Guang-huo, W.; Qi-chun, Z.; Guo, H.C. Effects of nitrogen fertilization strategies on nitrogen use efficiency in physiology, recovery, and agronomy and redistribution of dry matter accumulation and nitrogen accumulation in two typical rice cultivars in Zhejiang. China J. Zhejiang Univ. Sci. B 2007, 8, 208-216.

206. Yoshida, S. Fundamentals of Rice Crop Science; IRRI: Los Baños, Laguna, Philippines, 1981; 269p.

207. Amanullah; Muhammad, A.; Almas, L.K.; Amanullaj, J.; Zahir, S.; Rahman, H.; Khalil, S.K. Agronomic Efficiency and Profitability of P-Fertilizers Applied at Different Planting Densities of Maize in Northwest. Pak. J. Plant Nutr. 2012, 35, 331-341. [CrossRef] 
208. Rao, T.N. Improving nutrient use efficiency: The role of beneficial management practices. In Better Crops-India; IPNI-India Program 133: Gurgaon, India, 2007; Volume 1, pp. 6-7.

209. Singh, D.P. Vermiculture biotechnology and biocomposting. In Environmental Microbiology and Biotechnology; Singh, D.P., Dwivedi, S.K., Eds.; New Age International (P) Limited Publishers: Darya Ganj, New Delhi, 2004; pp. 97-112. 